\title{
Flood Sensitivity, Risk Perception, and Support for Climate Action in the United States*
}

\author{
Thomas Jamieson \\ School of Public Administration \\ University of Nebraska at Omaha \\ tjamieson@unomaha.edu
}

\begin{abstract}
Despite increasing evidence of the effects of climate change and scientific consensus about its threat, significant political barriers to climate action remain in the US. American public opinion about climate change is generally perceived as stable and sharply divided along partisan lines. However, less is known about the relationship between flood sensitivity and public opinion about climate change. Combining the ND-GAIN Urban Adaptation Assessment data of American cities with public opinion data from the Yale Program on Climate Change Communication, this paper demonstrates the positive association between flood sensitivity and beliefs about climate change, risk perceptions, and support for climate action. These results have important implications for the understanding of public opinion about climate change, suggesting that flood sensitivity shapes perceptions of climate change. The results also have important implications for advocates of political action, suggesting that making flood sensitivity salient could help mobilize public support for climate action.
\end{abstract}

Keywords: public opinion, flood sensitivity, risk perception, climate change, floods

Word count: 6,977 words (all inclusive)

\footnotetext{
* Earlier versions of this paper was presented at the US Political Resistance to Climate Action Workshop at the University of Notre Dame and the 2019 Natural Hazards Researchers Meeting in Bloomfield, Colorado. I would especially like to thank Lazarus Adua, Dontá Council, Matthew Dowiatt, Oronde Drakes, Rachel Gurney, Alan Hamlet, Feng Hao, Sara Hughes, Drew Marcantonio, Adam Mayer, Patrick Regan, Ragan Sernel, and participants in the panels for excellent comments and suggestions. Any errors that remain are my own responsibility.
} 


\section{Introduction}

Despite increasing evidence of the effects of climate change and scientific consensus about its threat, significant political barriers to climate action remain in the United States. Although the US signed the 2015 Paris Agreement, the Trump Administration subsequently withdrew from the agreement, and despite the Biden Administration's return to the agreement, partisan appointments to environmentally-focused federal departments further limit the chances of climate action in the near future.

Furthermore, US public opinion continues to lag behind scientific evidence. For example, in 2017 just 71 percent of Americans believed climate change is happening, 56 percent believed it is caused by humans, and 53 percent believed there is scientific consensus about climate change (Ballew et al. 2019 Mildenberger and Tingley, 2017). Public opinion about climate change is relatively stable, and sharply divided along partisan lines (Egan and Mullin, 2017). Furthermore, recent research suggests that beliefs about climate change among Republicans might even be overstated (Motta et al. 2019). In short, the prospects of climate action through public opinion in the US appear to be limited.

However, the prospect of political change may not be so remote. While some may be pessimistic about the prospects of bottom-up climate action (McAdam, 2017), prior research demonstrates that elected officials are broadly responsive to the policy preferences of their constituents (Drews and Bergh, 2016, Hagemann, Hobolt and Wratil, 2017; Page and Shapiro, 1983), and as the effects of climate change continue to affect Americans' lives, the public may demand climate action. Accordingly, public opinion could help create the conditions where politicians pass legislation that addresses climate change or face being forced out of office at the next election.

In many ways, climate change may have once appeared to be distant for many Americans, who may perceive there are few incentives to devote their scarce attention to learning about climatic change in their daily lives. However, for people who are particularly vulnerable to the effects of climate change, this calculus might shift with exposure to its effects. Instead, people who are likely to be most affected by these changes may be particularly aware of the dangers presented by the effects of climate change to their lives Ansolabehere and Konisky, 2014; Bernauer and McGrath, 2016). 
This paper uses data from the ND-GAIN Urban Adaptation Assessment and the Yale Program on Climate Change Communication to demonstrate the positive association between flood sensitivity and 1) beliefs about climate change, 2) risk perceptions about climate change, and 3) support for climate action. These results have important implications for the understanding of US public opinion about climate change, suggesting that a city's flood sensitivity shapes their perceptions of climate change. The results also have important implications for advocates of political action, suggesting that making flood sensitivity salient could help mobilize public support for climate action.

\section{US Public Opinion about Climate Change}

As described by Egan and Mullin (2017), public opinion about climate change is somewhat unusual because the extent of the problem and the underlying causes are disputed in the US, and climate change is arguably more remote to people's daily lives which might prevent people from making connections between events that they might make in different policy issues.

In spite of, or perhaps because of these unique properties of the climate change debate in the US, American attitudes about climate change have remained remarkably stable (Brulle, Carmichael and Jenkins, 2012, Egan and Mullin, 2017; Hamilton et al., 2015). Democrats and politically liberal individuals are considerably more likely to believe in climate change and support climate action (Krosnick, Holbrook and Visser, 2000; McCright and Dunlap, 2011), a symptom of the divergence between the two major parties on environmental issues since since the 1970s (Lindaman and HaiderMarkel, 2002, Shipan and Lowry, 2001).

Climate change skepticism has also arguably grown due to misinformation campaigns to dispute the underlying science on the political right (Elsasser and Dunlap, 2013; Jacques, Dunlap and Freeman, 2008; McCright and Dunlap, 2003, Oreskes and Conway, 2011), journalists' use of climate skeptics in the pursuit of balance in news coverage (Boykoff, 2007, 2008; Boykoff and Boykoff, 2007, McCright and Dunlap, 2003), and the Democratic Party's inability to pursue a coherent approach (Dunlap and McCright, 2008, McCright and Dunlap, 2003).

Beyond demographic factors, risk perception shapes attitudes to climate change. Hierarchical orientation (Hornsey et al., 2016; Kahan et al., 2012; Leiserowitz, 2006), and trust in science predict 
attitudes about climate change. However, if people perceive risk to themselves, they might be more likely to favor climate policies (Lorenzoni, Nicholson-Cole and Whitmarsh, 2007; Scannell and Gifford, 2013; Spence et al., 2011; Spence, Poortinga and Pidgeon, 2012; Weber, 2006), even if support of this contention is mixed (Brügger et al., 2015; Scannell and Gifford, 2013; Schoenefeld and McCauley, 2016; Shwom, Dan and Dietz, 2008; Spence and Pidgeon, 2010; Spence, Poortinga and Pidgeon, 2012). Furthermore, these interventions may even decrease support for climate action (Schoenefeld and McCauley, 2016, Spence and Pidgeon, 2010).

Recent research demonstrates that personal experience and vulnerability to climate change affect public opinion. Exposure to symptoms of climate change such as warmer temperatures, extreme weather, and natural hazards are potentially associated with increased belief in the existence of climate change (Deryugina, 2013, Druckman, 2015, Egan and Mullin, 2012, Joireman, Barnes Truelove and Duell, 2010; Konisky, Hughes and Kaylor, 2016; Zaval et al., 2014), although the duration of these effects might be limited (Druckman and Shafranek, 2016; Konisky, Hughes and Kaylor, 2016).

While excellent work has explored the effects of physical vulnerability to climate change on support for climate action (Brody et al., 2008; Harlan and Ruddell, 2011; Zahran et al., 2006), less is known about how social vulnerability shapes perceptions of climate change. Like many other

threats to human security, people who are already vulnerable are likely to be disproportionately affected by climate change, and this could shape public opinion about climate change Kim and Wolinsky-Nahmias, 2014). In this paper, I seek to explore this gap in the considerable literature on US public opinion about climate change in order to better understand how to overcome political barriers to climate action.

\section{Flood Sensitivity and Public Opinion about Climate Change}

While public opinion about climate change and political action might generally be stable over time, it is possible that flood sensitivity affects how people perceive the threat of climate change.

Previous research demonstrates that the people who suffer most from disasters are those who are already marginalized in society (Cutter, Boruff and Shirley, 2003; Thomas et al., 2013). In short, people who are most vulnerable to crisis in their everyday lives are also particularly vulnerable 
to disasters. This vulnerability likely affects how they interpret environmental issues, particularly regarding natural hazards and climate change (Füssel, 2007; Kelly and Adger, 2000b). Because of their increased vulnerability to the effects of disasters, people facing hardship are likely to be more aware of the environmental risks they face than people without this increased vulnerability.

Similarly, the greatest effects of climate change will be disproportionately felt by people who are already vulnerable Adger and Kelly, 1999; Bohle, Downing and Watts, 1994; Diffenbaugh and Burke, 2019; Füssel, 2007; Kelly and Adger, 2000a; Kim and Wolinsky-Nahmias, 2014; Ribot, Magalhães and Panagides, 2005). As a result of their increased vulnerability to natural hazards, and to the effects of climate change, socially vulnerable people are likely to perceive incentives to learn about climate change that might not be apparent to other members of society who are less exposed to the the consequences of climate change and better able to cope with them.

Prior research suggests that the perception of incentives for accuracy leads to improved political knowledge (Hill, 2017; Prior and Lupia, 2008), and improved accuracy in predicting future events (Jamieson and Weller, N.d.). It is likely that people who are particularly vulnerable to the effects of climate change perceive different incentives to learn about climate change than others. Social vulnerability could help foster a willingness among individuals to improve their knowledge about climate change to make informed decisions at the ballot box, which could overcome heuristics such as political ideology or party ID that could otherwise affect people's engagement with climate change (Kim and Wolinsky-Nahmias, 2014).

Among other hazards, urban flooding is likely to increase with climate change. Given people's incentives to learn about the risks they face in their area, people living in areas with high levels of flood sensitivity could be more attentive to climate change, and they could have different perceptions of climate change harm than those living in communities that are less vulnerable. The impact of flood sensitivity is measurable across three broad categories of public opinion at the city level: beliefs about climate change, risk perceptions about climate change, and support for climate action. As flood sensitivity in a city increases, we should expect to see increased belief in climate change, increased perception of the risks presented by climate change, and increased support for climate action to mitigate climate change. As such, the hypotheses are:

\section{Hypothesis 1 Flood Sensitivity and Beliefs Hypothesis}


As flood sensitivity increases, the number of people expressing belief in climate change increases.

Hypothesis 2 Flood Sensitivity and Risk Perceptions Hypothesis

As flood sensitivity increases, the number of people recognizing the risks of climate change increases.

Hypothesis 3 Flood Sensitivity and Climate Action Hypothesis

As flood sensitivity increases, the number of people expressing support for climate action increases.

\section{Data and Methods}

\subsection{Case Selection: Floods in the United States}

There are a number of different natural hazards that could lead people to become more cognizant of the threat posed by climate change, especially for those people with increased vulnerability relative to the rest of the population. However, of all hazards, floods present perhaps the best example of a hazard that could lead to increased awareness of the harm being caused by climate change. This paper examines how risk and vulnerability affects attitudes about climate change for several reasons.

First, floods are the most common natural hazard experienced by people in the US. In 2016 for example, the US suffered 36 floods that were called presidentially-declared disasters, with at least one of these events occurring in 25 states across the country. In short, floods affect large numbers of people across the US.

Second, floods have significant consequences. According to a recent Congressional Budget Office report, losses from storm-related flooding alone are expected to cost the US economy up to $\$ 47$ billion every year (Congressional Budget Office, 2019). To put this figure in context, this constitutes over 0.2 percent of the entire US gross domestic product in 2019. As part of the National Flood Insurance Program, alongside others, the federal government is expected to pay at least $\$ 17$ billion each year.

Third, there is considerable variation in the impacts of floods on communities around the United States, both in terms of direct economic losses and insured losses. Furthermore, floods are influenced by infrastructure policies, which can mitigate against them or exacerbate risk through levees, dams, flood banks, and related infrastructure. 
Because floods occur throughout the country, and because they are so costly, they are a useful means to evaluate how people might respond to their own vulnerability and exposure to events to consider the harm of climate change in the US. If riverine and flash floods occur regularly despite being labelled "100" or "1000-year events," people might make connections between the hazards and the impact of broader climatic change on their communities.

\subsection{Data}

\subsubsection{Dependent Variables: Public Opinion about Climate Change in the US}

For all analysis, dependent variables are the estimated percentage of public opinion that corresponds with each statement about climate change in a given city in the United States. Data was collected in 2016 by the Yale Project on Climate Change Communication as part of their national surveys of public opinion about climate change, and the city-level estimates were generated through multilevel regression and post-stratification, which is described in detail in Howe et al. (2015). There are three broad categories of public opinion about climate change that hold particular importance for the prospects of climate action in the US: 1) beliefs about climate change; 2) risk perceptions about climate change; and 3) support for climate action.

Beliefs about climate change tap into people's perceptions of climate change and global warming. These beliefs are critical for understanding public opinion about climate action - beliefs frequently shape the way people filter information. Risk perceptions measure how people perceive risk and harm relating to climate change. Risk perceptions are also important to understand as

they capture individuals' attitudes about the potential harm of climate change to themselves and their community. 
Table 1: Operationalization of Public Opinion about Climate Change in the US.

\section{Constructs and Measures}

Beliefs about Climate Change

- Estimated percentage who think that global warming is happening

- Estimated percentage who think that global warming is caused mostly by human activities

- Estimated percentage who believe that most scientists think global warming is happening

- Estimated percentage who somewhat or strongly trust climate scientists as a source of information about global warming

Risk Perceptions about Climate Change

- Estimated percentage who are somewhat/very worried about global warming

- Estimated percentage who think global warming will harm them personally a moderate amount/a great deal

- Estimated percentage who think global warming will harm people in the US a moderate amount/a great deal

- Estimated percentage who think global warming will harm people in developing countries a moderate amount/a great deal

- Estimated percentage who think global warming will harm future generations a moderate amount/a great deal

- Estimated percentage who think global warming will start to harm people in the United States now/within 10 years

- Estimated percentage who think global warming will harm plants and animal species a moderate amount/a great deal

Support for Climate Action

- Estimated percentage who somewhat/strongly support setting strict limits on existing coal-fire power plants

- Estimated percentage who somewhat/strongly support regulating CO2 as a pollutant

- Estimated percentage who somewhat/strongly support requiring utilities to produce $20 \%$ electricity from renewable sources

- Estimated percentage who somewhat/strongly support funding research into renewable energy sources

Source: Yale Project on Climate Change Communication (Howe et al. 2015 ). 
Finally, arguably the most critical element of public opinion for the prospects of climate action involves support for climate policy. If public opinion coalesces around support for climate action, elected officials are likely to pursue these policies or risk being voted out of office at the next election. Table 1 describes how each of these constructs are operationalized into variables for analysis.

\subsubsection{Independent Variable}

The independent variable is flood sensitivity. In this paper, flood sensitivity is operationalized and measured through the "Flood Sensitivity" index in the ND-GAIN Urban Adaptation Assessment (UAA) dataset, developed by the Notre Dame Global Adaptation Initiative (2018).

This index is created through calculating the average of each individual indicator's score for each given hazard. This is measured as the average of indicators of flood sensitivity in a city such as the percent of area that is impervious surface, the percent of population residing in mobile homes, the percent of population that is 65 years or older living along, the percent of population that is 5 years old or younger, the percent of households without access to a vehicle, the percent of buildings built before 1999, and the percent of population spending over 50 percent of income on rent. These social and physical vulnerabilities combine to capture flood sensitivity in a city.

\subsubsection{Control Variables}

A series of control variables are used to account for alternative explanations about factors that could affect public opinion about climate change harm in the US after exposure to floods.

First, flood experience could influence attitudes about climate change harm. In particular, recent experience of floods could increase the acknowledgement of climate change harm in affected communities (Deryugina, 2013, Druckman, 2015, Egan and Mullin, 2012, Joireman, Barnes Truelove and Duell, 2010; Konisky, Hughes and Kaylor, 2016, Zaval et al., 2014). Flood experience could lead to changes in attitudes about climate change harm as the amount of damage increases (Thistlethwaite et al., 2018). As a result, flood damage (logged) is included in the analysis, with data coming from the National Oceanic and Atmospheric Administration (NOAA), and reported in the UAA data (Notre Dame Global Adaptation Initiative, 2018).

Second, four indices reported in the UAA dataset related to flooding could also conceivably influence attitudes about climate change harm. These include flood exposure, flood adaptive ca- 
Table 2: Indices and Indicators.

\begin{tabular}{ll}
\hline Index & Indicators \\
\hline Flood Sensitivity & Percent of area that is impervious surface \\
& Percent of population residing in mobile homes \\
& Percent of population that is 65 years old or older living alone \\
& Percent of population that is 5 years old or younger \\
& Percent of households without access to a vehicle \\
& Percent of buildings built before 1999 \\
& Percent of population spending over 50 percent of income on rent \\
& Percent of cars in floodzone \\
& Percent of population in floodzone \\
& Percent of buildings in floodzone \\
& Number of acute care hospital beds available per 1000 residents \\
Flood Adaptive Capacity & Percent of population with health insurance \\
& Water quality \\
& Civic Engagement \\
& General innovation capabilities \\
Flood Social Readiness & City debt \\
Flood Economic Readiness & Tax incentives for renewable energy \\
\hline
\end{tabular}

Source: Notre Dame Global Adaptation Initiative (2018). 
pacity, flood social readiness, and flood economic readiness. These are produced through the same process as the index for flood sensitivity 11 Further details about each index and the individual indicators used to produce the indices are presented in Table 1.

Third, previous research demonstrates that Republicans are more skeptical of climate change and less supportive of climate action (Elsasser and Dunlap, 2013; Jacques, Dunlap and Freeman, 2008; Krosnick, Holbrook and Visser, 2000; McCright and Dunlap, 2003, 2011; Oreskes and Conway, 2011). To account for partisanship as an alternative explanation, the proportion of votes for Donald Trump in the 2016 Presidential election in a city is included as a control variable. The variable is constructed by dividing the number of votes for Trump by the total population of the city in 2016 as estimated by the US Census Bureau (Daily Kos Staff, 2018; Notre Dame Global Adaptation Initiative, 2018).

Finally, standard demographic variables such as the total population (log), median income, and the percentage of the population with a 12th Grade education or below are also included to control for the possibility these factors shape public opinion about climate change. This data comes from the US Census Bureau and is reported in the UAA dataset Notre Dame Global Adaptation Initiative, 2018).

Appendix A in the Supplementary Materials presents descriptive statistics for all variables. The table indicates the wide amount of variation in the dependent and independent variables of interest.

\subsection{Methods}

I use a series of simple OLS regressions with robust standard errors to assess the relationship between the independent variables and beliefs, risk perceptions, and support for climate action in the US. The unit of analysis is the city, and the model can be expressed as:

$$
\text { PublicOpinion }_{i}=\beta_{1} \text { FloodSensitivity }_{i}+u_{i},
$$

where PublicOpinion $i$ refers to the percentage of adults sharing a given belief, risk perception, or support for climate action in a city $i$.

\footnotetext{
${ }^{1}$ Food governance is not included in the analysis because the index includes public opinion about climate change.
} 
Figure 1: Public Beliefs about Climate Change in the US.

Dependent Variables: Estimated Percentage of Public Belief in each Statement.

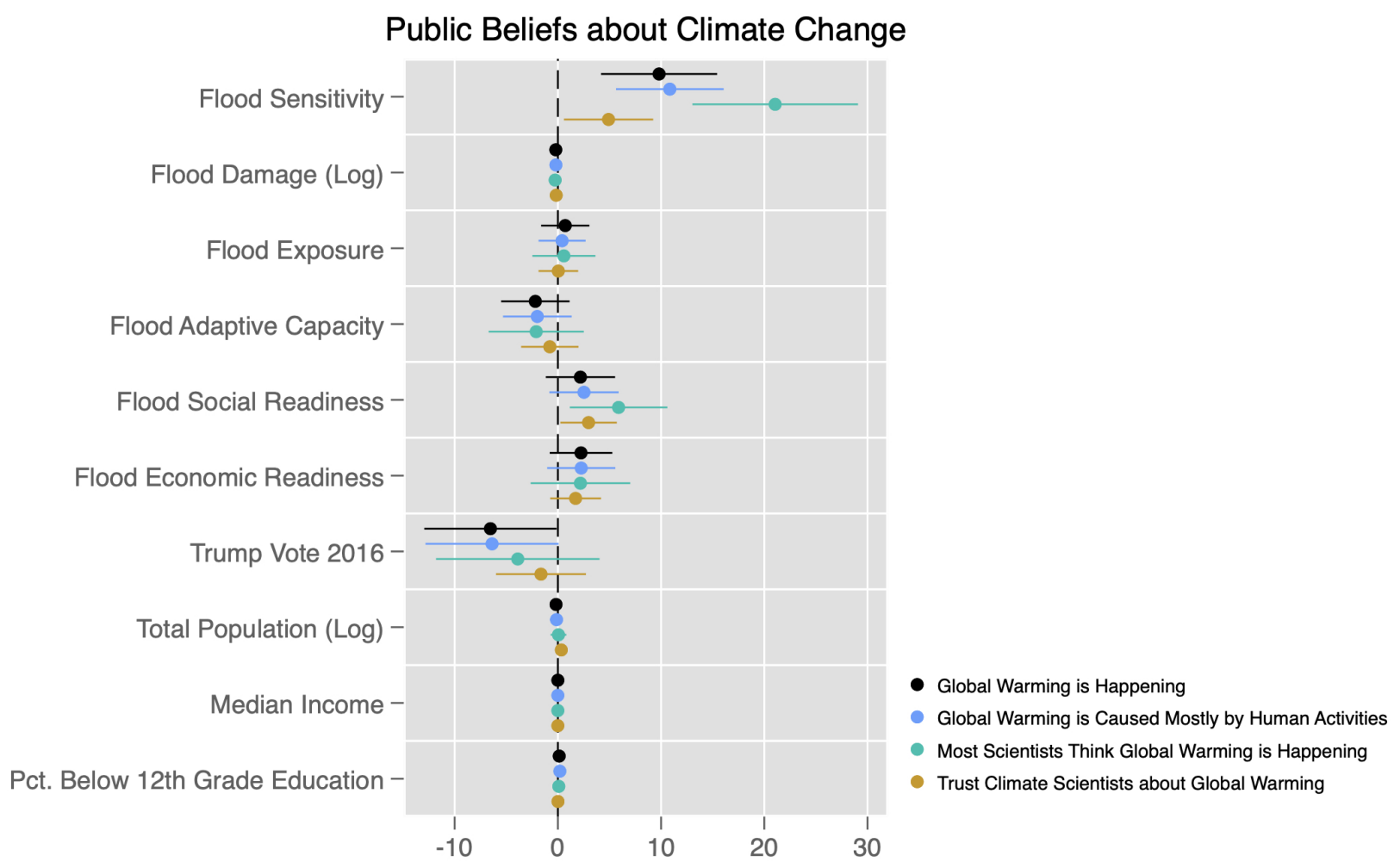

\section{Results}

The results broadly support the hypotheses presented in the paper. While controlling for alternative explanations, the analysis indicates that flood sensitivity is positively associated with beliefs about climate change, risk perceptions about the harm of climate change, and support for climate action to mitigate against climate change ${ }^{2}$

\subsection{Flood Sensitivity and Beliefs about Climate Change}

Figure 1 presents the results of OLS regressions on beliefs about climate change in the US with all control variables included. Across all models, as flood sensitivity increases, the percentage of opinion indicating belief in climate change increases. There are several main implications of these results.

\footnotetext{
${ }^{2}$ Full results and additional robustness checks are presented in the Supplementary Materials.
} 
First, the results indicate that flood sensitivity is positively associated with beliefs about climate change. Substantively, for every one unit increase in flood sensitivity, the number of people who believe global warming is happening increases by 9.806 percent, the number of people who believe global warming is caused mostly by human activities increases by 10.85 percent, the number of people who believe most scientists think global warming is happening increases by 21.056 percent, and the number of people who trust climate scientists about global warming increases by 4.913 percent. In sum, these results indicate we can reject the null hypothesis of flood sensitivity having no relationship with beliefs about climate change. Instead, as flood sensitivity increases, people increasingly believe climate change is happening and that there is scientific consensus about this fact.

Second, the results indicate that flood damage is negatively associated with beliefs about climate change harm. Although the magnitude of the effect are relatively small, it appears that direct flood experience may actually reduce beliefs about climate change.

Third, as one might expect, the proportion of the city voting for Donald Trump in the 2016 Presidential election is negatively associated with beliefs about climate change, although the correlation is only statistically significant at $\mathrm{p}>0.05$ for the belief that global warming is happening and $\mathrm{p}>0.1$ for the belief that global warming is caused mostly by human activities. These results are broadly in line with what one might expect given widespread Republican skepticism of climate change, but they also suggest that the correlation between flood sensitivity and beliefs in climate change are not simply an artifact of partisan politics in urban areas.

\subsection{Flood Sensitivity and Risk Perceptions}

Next, the relationship between flood sensitivity and risk perceptions about climate change is presented in Figure 2. Again, flood sensitivity is associated with increased perceptions of risks related to climate change.

Cities with greater flood sensitivity are much more likely to indicate worry about the harms of climate change. Substantively, in full models with all covariates included, a one unit increase in flood sensitivity is associated with a 14.886 percent increase in the number of people worried about global warming, a 8.686 percent increase in the number of people worried global warming will harm them personally, a 11.918 percent increase in the number of people worried that global 
Figure 2: Public Risk Perceptions about Climate Change in the US.

Dependent Variables: Estimated Percentage of Public Perception of each Risk.

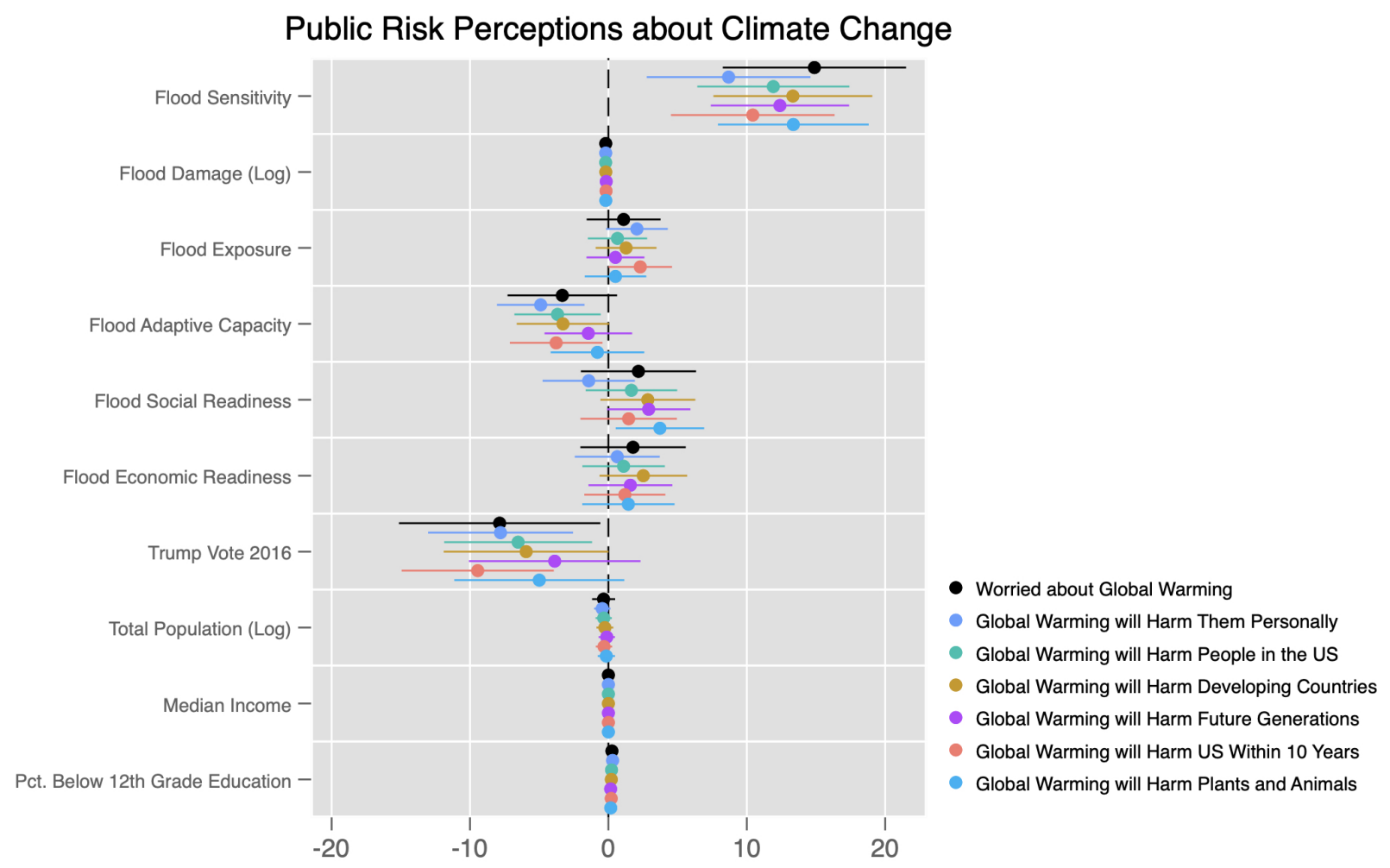

warming will harm people in the US, a 13.329 percent increase in the number of people worried that global warming will harm developing countries, a 12.395 percent increase in the number of people worried that global warming will harm future generations, a 10.433 percent increase in the number of people worried that global warming will harm the US now or within 10 years, and a 13.362 percent increase in the number of people worried that global warming will harm plants and animals.

There are several other notable results worth further discussion. First, flood damage was negatively associated with risk perception, indicating that previous experiences of floods may perversely reduce the likelihood of people worrying about the effects of climate change, despite exposure to hazards that are exacerbated by changes in climatic conditions.

Second, flood adaptive capacity is negatively associated with risk perception for many, if not all, risk perceptions. In many ways adaptive capacity captures a city's ability to cope with a disaster, where flood sensitivity measures the absence of this ability. As a result, it is perhaps unsurprising 
that people living in cities with greater numbers of hospital beds per capita, higher levels of health insurance coverage, and increased water quality are less concerned about the effects of climate change as they are less exposed to its effects.

Finally, the 2016 Trump vote is negatively associated with most risk perceptions, again suggesting that cities with larger numbers of Republican voters are less worried about the effects of climate change than other communities.

\subsection{Flood Sensitivity and Support for Climate Action}

Finally, flood sensitivity is associated with increased support for climate action. Figure 3 presents the results of regressions on four climate policies.

In short, flood sensitivity is not just associated with greater belief in climate change and greater worry about its effects, but this vulnerability leads to increased support for policies that mitigate against climate change. A one unit increase in flood sensitivity is associated with a 13.783 percent increase in support for strict limits on coal-fire power plants, a 9.519 percent increase in support for regulating carbon dioxide as a pollutant, a 8.480 percent increase in support for requiring utilities to produce at least 20 percent of their electricity from renewable sources, and a 5.735 percent increase in support for funding research into renewable energy sources. In short, communities with large levels of flood sensitivity have increased support for climate action.

Flood social readiness is also positively associated with support for climate action. As social readiness measures civic engagement and innovation capacity, this suggests that cities in a good position to take action are more inclined to support climate action, which presents some reasons for optimism about the prospects of climate action in these communities.

In sum, flood sensitivity is positively associated with beliefs about climate change, worry about the harms of climate change, and support for climate action to mitigate against climate change. These results suggest that communities with greater numbers of people vulnerable to the effects of climate change are more aware of the effects of climate change, and more willing to pursue climate action. 
Figure 3: Public Support for Climate Action in the U.S.

Dependent Variables: Estimated Percentage of Public Support for each Policy.

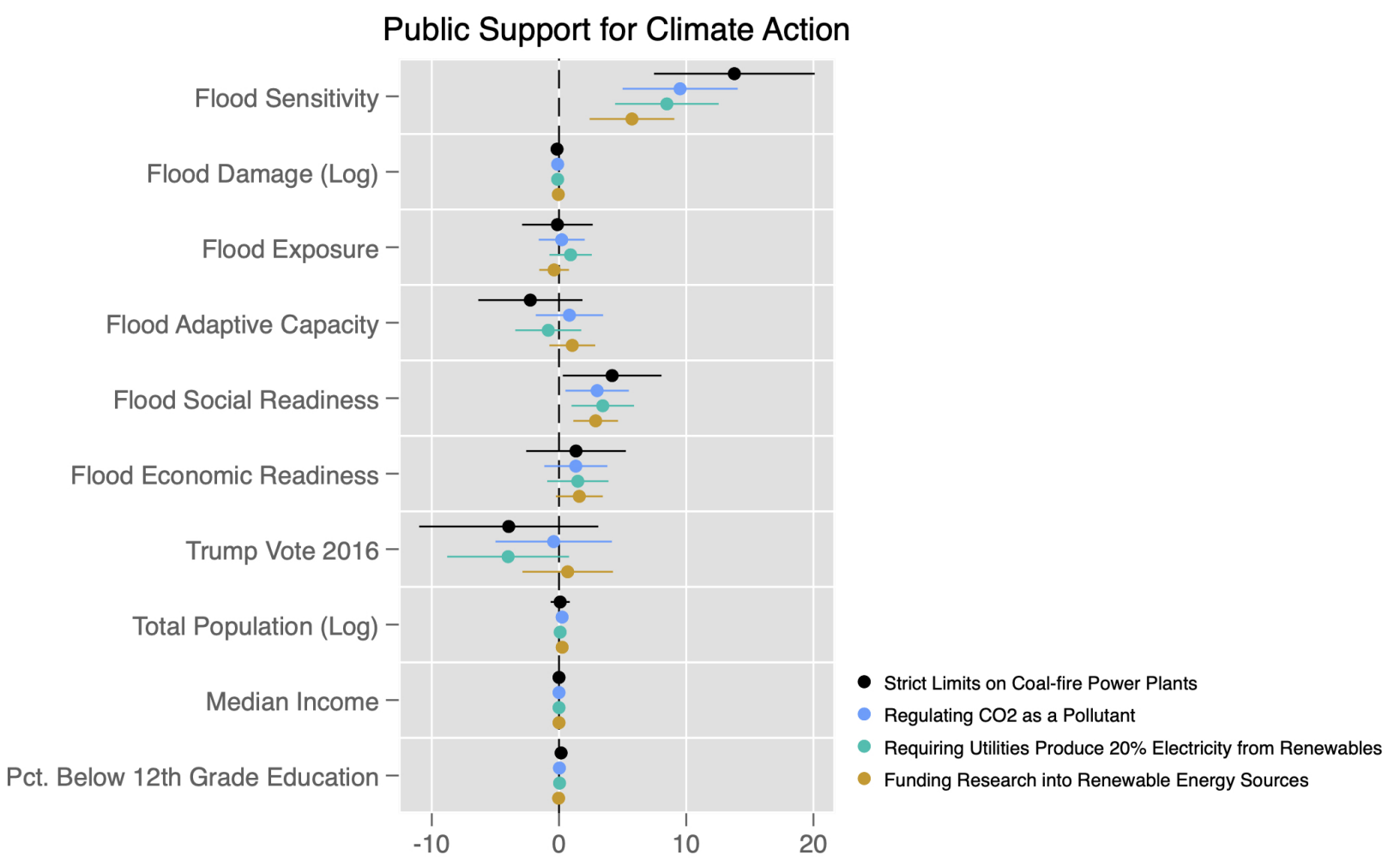




\section{Discussion}

Flood sensitivity appears to be an important factor in shaping people's beliefs, risk perceptions, and ultimately their support for climate action. This presents reasons for optimism about the prospects of climate action. While scholars and advocates of climate action cannot and should not directly manipulate flood sensitivity, making these risks salient in discussions of climate change could help people become more aware of the threat it presents to communities around the US.

Activists and lobby groups could garner increased support for climate action by highlighting communities' flood sensitivity in their messages, especially if they emphasize how the effects of climate change will disproportionately affect already-vulnerable groups in society. By making this salient, even some of the more traditionally resistant groups like Republican voters might be drawn to accept the reality of climate change, acknowledge the harms of climate change, and support climate action to reduce the costs of climate change.

If campaigns make flood sensitivity salient, it might be possible to further increase support for climate action and force politicians to comply with the policy preferences of their constituents and address climate change through legislation. As more people become exposed to the effects of climate change, these shifts in public opinion could be leveraged to influence public policy.

However, it is important to acknowledge some limitations of this study that future work should address. First, the paper provides a window into the dynamics of public opinion about climate change, but it does not test how this affects the likelihood of political action. Further research should study how public opinion about climate change translates into subsequent political action.

Second, while the UAA data helps to provide evidence in support of the hypotheses in this paper, causal inference is difficult given the observational nature of the data. Future research should use experiments to test the causal mechanisms leading from flood sensitivity to public opinion about climate change.

Third, it is worth considering the state of public knowledge about their own community. While some of the indicators in the data might be widely known by people living in each community, some are more likely to be unknown. Further work could examine public knowledge of community vulnerability, and then test how knowledge accuracy affects attitudes about climate change.

Finally, the data present a single snapshot in time where there is a single observation for 
every city. As more data is collected and published, longitudinal studies would further increase our understanding of public opinion about climate change, and the duration of effects of flood sensitivity over time.

Despite these limitations, this paper makes an important contribution by demonstrating the relationship between flood sensitivity and public opinion about climate change. It shows the communities that are most susceptible to the effects of climate change are most supportive of climate action. This suggests that vulnerable communities connect the dots between their flood sensitivity and the present and future threat of climate change. Further work should build on this research to understand how flood sensitivity affects public opinion, and ultimately examine how public opinion translates into political action to address climate change. 


\section{References}

Adger, W. Neil. 1999. "Social Vulnerability to Climate Change and Extremes in Coastal Vietnam." World Development 27(2):249-269.

Adger, W. Neil and P. Mick Kelly. 1999. "Social vulnerability to climate change and the architecture of entitlements." Mitigation and adaptation strategies for global change 4(3-4):253-266.

Ansolabehere, Stephen and David M. Konisky. 2014. Cheap and Clean: How Americans Think about Energy in the Age of Global Warming. Cambridge, MA: MIT Press.

Ballew, Matthew T., Matthew H. Goldberg, Seth A. Rosenthal, Abel Gustafson and Anthony Leiserowitz. 2019. "Systems thinking as a pathway to global warming beliefs and attitudes through an ecological worldview." Proceedings of the National Academy of Sciences 116(17):82148219 .

Bernauer, Thomas and Liam F. McGrath. 2016. "Simple reframing unlikely to boost public support for climate policy." Nature Climate Change 6(7):680-683.

Bohle, Hans G., Thomas E. Downing and Michael J. Watts. 1994. "Climate change and social vulnerability: toward a sociology and geography of food insecurity." Global environmental change 4(1):37-48.

Boykoff, Maxwell T. 2007. "Flogging a dead norm? Newspaper coverage of anthropogenic climate change in the United States and United Kingdom from 2003 to 2006." Area 39(4):470-481.

Boykoff, Maxwell T. 2008. "Lost in translation? United States television news coverage of anthropogenic climate change, 1995-2004." Climatic Change 86(1):1-11.

Boykoff, Maxwell T. and Jules M. Boykoff. 2007. "Climate change and journalistic norms: A case-study of US mass-media coverage." Geoforum 38(6):1190-1204.

Brody, Samuel D., Sammy Zahran, Arnold Vedlitz and Himanshu Grover. 2008. "Examining the Relationship Between Physical Vulnerability and Public Perceptions of Global Climate Change in the United States." Environment and Behavior 40(1):72-95.

Brulle, Robert J., Jason Carmichael and J. Craig Jenkins. 2012. "Shifting public opinion on climate change: an empirical assessment of factors influencing concern over climate change in the U.S., 2002-2010." Climatic Change 114(2):169-188.

Brügger, Adrian, Suraje Dessai, Patrick Devine-Wright, Thomas A. Morton and Nicholas F. Pidgeon. 2015. "Psychological responses to the proximity of climate change." Nature Climate Change 5(12):1031-1037.

Congressional Budget Office. 2019. Expected Costs of Damage From Hurricane Winds and StormRelated Flooding | Congressional Budget Office. Technical Report 55019 Congressional Budget Office Washington, D.C.: .

Cutter, Susan L., Bryan J. Boruff and W. Lynn Shirley. 2003. "Social Vulnerability to Environmental Hazards." Social Science Quarterly 84(2):242-261.

Daily Kos Staff. 2018. "The ultimate Daily Kos Elections guide to all of our data sets.". URL: https://www.dailykos.com/story/2018/2/21/1742660/-The-ultimate-Daily-Kos-Electionsguide-to-all-of-our-data-sets

Deryugina, Tatyana. 2013. "How do people update? The effects of local weather fluctuations on beliefs about global warming." Climatic Change 118(2):397-416.

Diffenbaugh, Noah S. and Marshall Burke. 2019. "Global warming has increased global economic inequality." Proceedings of the National Academy of Sciences p. 201816020.

Drews, Stefan and Jeroen C. J. M. van den Bergh. 2016. "What explains public support for climate policies? A review of empirical and experimental studies." Climate Policy 16(7):855-876.

URL: https://doi.org/10.1080/14693062.2015.1058240

Druckman, James N. 2015. "Eliminating the local warming effect." Nature Climate Change 
$5(3): 176-177$.

Druckman, James N. and Richard M. Shafranek. 2016. "The Conditional Nature of the Local Warming Effect." Weather, Climate, and Society 9(1):15-26.

Dunlap, Riley E. and Araon M. McCright. 2008. "A Widening Gap: Republican and Democratic Views on Climate Change." Environment: Science and Policy for Sustainable Development 50(5):26-35.

Egan, Patrick J. and Megan Mullin. 2012. "Turning Personal Experience into Political Attitudes: The Effect of Local Weather on Americans' Perceptions about Global Warming." The Journal of Politics 74(3):796-809.

Egan, Patrick J. and Megan Mullin. 2017. "Climate change: US public opinion." Annual Review of Political Science 20:209-227.

Elsasser, Shaun W. and Riley E. Dunlap. 2013. "Leading Voices in the Denier Choir: Conservative Columnists' Dismissal of Global Warming and Denigration of Climate Science." American Behavioral Scientist 57(6):754-776.

Füssel, Hans-Martin. 2007. "Vulnerability: A generally applicable conceptual framework for climate change research." Global environmental change 17(2):155-167.

Hagemann, Sara, Sara B. Hobolt and Christopher Wratil. 2017. "Government Responsiveness in the European Union: Evidence From Council Voting." Comparative Political Studies 50(6):850876.

URL: https://doi.org/10.1177/0010414015621077

Hamilton, Lawrence C., Joel Hartter, Mary Lemcke-Stampone, David W. Moore and Thomas G. Safford. 2015. "Tracking Public Beliefs About Anthropogenic Climate Change." PLOS ONE 10(9):e0138208.

Harlan, Sharon L and Darren M Ruddell. 2011. "Climate change and health in cities: impacts of heat and air pollution and potential co-benefits from mitigation and adaptation." Current Opinion in Environmental Sustainability 3(3):126-134.

Hill, Seth J. 2017. "Learning Together Slowly: Bayesian Learning about Political Facts." The Journal of Politics 79(4):1403-1418.

Hornsey, Matthew J., Emily A. Harris, Paul G. Bain and Kelly S. Fielding. 2016. "Meta-analyses of the determinants and outcomes of belief in climate change." Nature Climate Change 6(6):622626.

Howe, Peter D., Matto Mildenberger, Jennifer R. Marlon and Anthony Leiserowitz. 2015. "Geographic variation in opinions on climate change at state and local scales in the USA." Nature Climate Change 5(6):596-603.

Jacques, Peter J., Riley E. Dunlap and Mark Freeman. 2008. "The organisation of denial: Conservative think tanks and environmental scepticism." Environmental Politics 17(3):349-385.

Jamieson, Thomas and Nicholas Weller. N.d. "The Effects of Certain and Uncertain Incentives on Effort and Knowledge Accuracy." Journal of Experimental Political Science. Forthcoming.

Jann, Ben. 2014. "Plotting Regression Coefficients and Other Estimates." The Stata Journal 14(4):708-737.

Joireman, Jeff, Heather Barnes Truelove and Blythe Duell. 2010. "Effect of outdoor temperature, heat primes and anchoring on belief in global warming." Journal of Environmental Psychology 30(4):358-367.

Kahan, Dan M., Ellen Peters, Maggie Wittlin, Paul Slovic, Lisa Larrimore Ouellette, Donald Braman and Gregory Mandel. 2012. "The polarizing impact of science literacy and numeracy on perceived climate change risks." Nature Climate Change 2(10):732-735.

Kelly, P. Mick and W. Neil Adger. 2000a. "Theory and practice in assessing vulnerability to climate change and Facilitating adaptation." Climatic change 47(4):325-352. 
Kelly, P. Mick and W. Neil Adger. 2000b. "Theory and practice in assessing vulnerability to climate change andFacilitating adaptation." Climatic change 47(4):325-352.

Kim, So Young and Yael Wolinsky-Nahmias. 2014. "Cross-National Public Opinion on Climate Change: The Effects of Affluence and Vulnerability." Global Environmental Politics 14(1):79106.

Konisky, David M., Llewelyn Hughes and Charles H. Kaylor. 2016. "Extreme weather events and climate change concern." Climatic Change 134(4):533-547.

Krosnick, Jon A., Allyson L. Holbrook and Penny S. Visser. 2000. "The impact of the fall 1997 debate about global warming on American public opinion." Public Understanding of Science 9(3):239-260.

Leiserowitz, Anthony. 2006. "Climate Change Risk Perception and Policy Preferences: The Role of Affect, Imagery, and Values." Climatic Change 77(1):45-72.

Lindaman, Kara and Donald P. Haider-Markel. 2002. "Issue Evolution, Political Parties, and the Culture Wars." Political Research Quarterly 55(1):91-110.

Lorenzoni, Irene, Sophie Nicholson-Cole and Lorraine Whitmarsh. 2007. "Barriers perceived to engaging with climate change among the UK public and their policy implications." Global Environmental Change 17(3):445-459.

McAdam, Doug. 2017. "Social Movement Theory and the Prospects for Climate Change Activism in the United States." Annual Review of Political Science 20(1):189-208.

McCright, Aaron M. and Riley E. Dunlap. 2003. "Defeating Kyoto: The Conservative Movement's Impact on U.S. Climate Change Policy." Social Problems 50(3):348-373.

McCright, Aaron M. and Riley E. Dunlap. 2011. "Cool dudes: The denial of climate change among conservative white males in the United States." Global Environmental Change 21(4):1163-1172.

Mildenberger, Matto and Dustin Tingley. 2017. "Beliefs about Climate Beliefs: The Importance of Second-Order Opinions for Climate Politics." British Journal of Political Science pp. 1-29.

Motta, Matthew, Daniel Chapman, Dominik Stecula and Kathryn Haglin. 2019. "An experimental examination of measurement disparities in public climate change beliefs." Climatic Change .

URL: https://t.co/PxJ846jep V

Notre Dame Global Adaptation Initiative. 2018. "Urban Adaptation | Notre Dame Global Adaptation Initiative | University of Notre Dame.".

URL: https://gain.nd.edu/our-work/urban-adaptation/

Oreskes, Naomi and Erik M. Conway. 2011. Merchants of Doubt: How a Handful of Scientists Obscured the Truth on Issues from Tobacco Smoke to Global Warming. Reprint edition ed. New York, NY: Bloomsbury Press.

Page, Benjamin I. and Robert Y. Shapiro. 1983. "Effects of Public Opinion on Policy." American Political Science Review 77(1):175-190.

URL: https://www.cambridge.org/core/journals/american-political-sciencereview/article/effects-of-public-opinion-on-policy/856B172A7DC19A7EB72C569A7F6F2104

Prior, Markus and Arthur Lupia. 2008. "Money, Time, and Political Knowledge: Distinguishing Quick Recall and Political Learning Skills." American Journal of Political Science 52(1):169-183.

Ribot, Jesse C., Antonio Rocha Magalhães and Stahis Panagides. 2005. Climate variability, climate change and social vulnerability in the semi-arid tropics. Cambridge University Press.

Scannell, Leila and Robert Gifford. 2013. "Personally Relevant Climate Change: The Role of Place Attachment and Local Versus Global Message Framing in Engagement." Environment and Behavior 45(1):60-85.

Schoenefeld, Jonas J. and Michelle R. McCauley. 2016. "Local is not always better: the impact of climate information on values, behavior and policy support." Journal of Environmental Studies and Sciences 6(4):724-732. 
Shipan, Charles R. and William R. Lowry. 2001. "Environmental Policy and Party Divergence in Congress." Political Research Quarterly 54(2):245-263.

Shwom, Rachael, Amy Dan and Thomas Dietz. 2008. "The effects of information and state of residence on climate change policy preferences." Climatic Change 90(4):343.

Spence, A., W. Poortinga, C. Butler and N. F. Pidgeon. 2011. "Perceptions of climate change and willingness to save energy related to flood experience." Nature Climate Change 1(1):46-49.

Spence, Alexa and Nick Pidgeon. 2010. "Framing and communicating climate change: The effects of distance and outcome frame manipulations." Global Environmental Change 20(4):656-667.

Spence, Alexa, Wouter Poortinga and Nick Pidgeon. 2012. "The Psychological Distance of Climate Change." Risk Analysis 32(6):957-972.

Thistlethwaite, Jason, Daniel Henstra, Craig Brown and Daniel Scott. 2018. "How Flood Experience and Risk Perception Influences Protective Actions and Behaviours among Canadian Homeowners." Environmental Management 61(2):197-208.

Thomas, Deborah S. K., Brenda D. Phillips, William E. Lovekamp and Alice Fothergill, eds. 2013. Social Vulnerability to Disasters. 2 edition ed. Boca Raton: CRC Press.

Weber, Elke U. 2006. "Experience-Based and Description-Based Perceptions of Long-Term Risk: Why Global Warming does not Scare us (Yet)." Climatic Change 77(1):103-120.

Zahran, Sammy, Samuel D. Brody, Himanshu Grover and Arnold Vedlitz. 2006. "Climate Change Vulnerability and Policy Support." Society \& Natural Resources 19(9):771-789.

Zaval, Lisa, Elizabeth A. Keenan, Eric J. Johnson and Elke U. Weber. 2014. "How warm days increase belief in global warming." Nature Climate Change 4(2):143-147. 


\section{A Appendix A. Descriptive Statistics}

Table 3: Descriptive Statistics.

\begin{tabular}{|c|c|c|c|c|c|}
\hline & Count & Mean & Std. Dev. & Min. & Max. \\
\hline \multicolumn{6}{|l|}{ Beliefs about Climate Change } \\
\hline Estimated percentage who think that global warming is happening & 218 & 71.47381 & 4.385587 & 60.476 & 81.68 \\
\hline Estimated percentage who think that global warming is caused mostly by human activities & 218 & 54.63254 & 4.584461 & 45 & 64.689 \\
\hline Estimated percentage who believe that most scientists think global warming is happening & 218 & 50.99912 & 6.367387 & 38.843 & 66.52 \\
\hline $\begin{array}{l}\text { Estimated percentage who somewhat or strongly trust climate scientists as a source of information about global warming } \\
\text { Risk Perceptions about Climate Change }\end{array}$ & 218 & 72.24718 & 3.067727 & 63.519 & 77.798 \\
\hline Estimated percentage who are somewhat/very worried about global warming & 218 & 59.49885 & 5.694448 & 48.163 & 72.039 \\
\hline Estimated percentage who think global warming will harm them personally a moderate amount/a great deal & 218 & 41.35174 & 5.100711 & 32.668 & 54.785 \\
\hline Estimated percentage who think global warming will harm people in the US a moderate amount/a great deal & 218 & 59.17304 & 4.790825 & 50.274 & 70.013 \\
\hline Estimated percentage who think global warming will harm people in developing countries a moderate amount/a great deal & 218 & 64.29268 & 4.839016 & 54.033 & 75.12 \\
\hline Estimated percentage who think global warming will harm future generations a moderate amount/a great deal & 218 & 70.99783 & 4.21941 & 62.505 & 79.596 \\
\hline Estimated percentage who think global warming will start to harm people in the United States now/within 10 years & 218 & 52.03257 & 4.737118 & 42.688 & 64.284 \\
\hline $\begin{array}{l}\text { Estimated percentage who think global warming will harm plants and animal species a moderate amount/a great deal } \\
\text { Support for Climate Action }\end{array}$ & 218 & 70.44015 & 4.506658 & 60.776 & 79.148 \\
\hline Estimated percentage who somewhat/strongly support setting strict limits on existing coal-fire power plants & 218 & 70.73089 & 5.035911 & 58.152 & 80.893 \\
\hline Estimated percentage who somewhat/strongly support regulating $\mathrm{CO} 2$ as a pollutant & 218 & 75.12597 & 3.01523 & 65.565 & 80.191 \\
\hline Estimated percentage who somewhat/strongly support requiring utilities to produce $20 \%$ electricity from renew & 218 & 66.94727 & 3.097799 & 58.207 & 73.327 \\
\hline Estimated percentage who somewhat/strongly support funding research into renewable energy sources & 218 & 82.44836 & 2.187237 & 76.803 & 87.365 \\
\hline Flood Sensitivity & 218 & .4815182 & .1298465 & .1841519 & .778482 \\
\hline Flood Damage (Log) & 158 & 12.98015 & 3.02747 & 4.043051 & 21.418 \\
\hline Flood Exposure & 218 & .3150496 & .2279429 & 0 & .9467379 \\
\hline Flood Adaptive Capacity & 218 & .581974 & .1877756 & .0767099 & .9854249 \\
\hline Flood Social Readiness & 218 & .3830727 & .2003148 & .018305 & .9490986 \\
\hline Flood Economic Readiness & 218 & .4714915 & .1816562 & .0153456 & .9408811 \\
\hline Trump Vote 2016 & 218 & .13201 & .1277485 & .0086272 & .6581846 \\
\hline Total Population (Log) & 218 & 15.68042 & 1.691636 & 11.0457 & 19.64042 \\
\hline Median Income & 218 & 52626.52 & 15519.17 & 25764 & 114098 \\
\hline Pct. Below 12th Grade Education & 218 & 14.41009 & 6.891168 & 2.4 & 45.2 \\
\hline
\end{tabular}




\section{B Appendix B. Full Results and Robustness Checks}

\section{B.1 Full Models with all Covariates}

Table 4: OLS Regression: Public Beliefs about Climate Change.

\begin{tabular}{|c|c|c|c|c|}
\hline & Global Warming Happening & Caused by Human Activities & Scientific Consensus & Trust Climate Scientists \\
\hline \multirow[t]{2}{*}{ Flood Sensitivity } & $9.806^{* * *}$ & $10.850^{* * *}$ & $21.056^{* * *}$ & $4.913^{*}$ \\
\hline & $(2.846)$ & $(2.639)$ & $(4.058)$ & $(2.187)$ \\
\hline \multirow[t]{2}{*}{ Flood Damage (Log) } & $-0.199^{*}$ & $-0.188^{*}$ & $-0.261^{+}$ & $-0.159^{*}$ \\
\hline & $(0.091)$ & $(0.095)$ & $(0.140)$ & $(0.066)$ \\
\hline \multirow[t]{2}{*}{ Flood Exposure } & 0.714 & 0.410 & 0.585 & 0.046 \\
\hline & $(1.183)$ & $(1.154)$ & $(1.546)$ & $(0.972)$ \\
\hline \multirow[t]{2}{*}{ Flood Adaptive Capacity } & -2.180 & -1.989 & -2.098 & -0.781 \\
\hline & $(1.678)$ & $(1.682)$ & $(2.332)$ & $(1.406)$ \\
\hline \multirow[t]{2}{*}{ Flood Social Readiness } & 2.190 & 2.532 & $5.884^{*}$ & $2.975^{*}$ \\
\hline & $(1.698)$ & $(1.698)$ & $(2.392)$ & $(1.383)$ \\
\hline \multirow{2}{*}{ Flood Economic Readiness } & 2.244 & 2.265 & 2.187 & 1.719 \\
\hline & $(1.533)$ & $(1.670)$ & $(2.441)$ & $(1.246)$ \\
\hline \multirow[t]{2}{*}{ Trump Vote 2016} & $-6.532^{*}$ & $-6.375^{+}$ & -3.884 & -1.636 \\
\hline & $(3.244)$ & $(3.263)$ & $(4.009)$ & $(2.206)$ \\
\hline \multirow[t]{2}{*}{ Total Population (Log) } & -0.174 & -0.128 & 0.061 & 0.333 \\
\hline & $(0.307)$ & $(0.319)$ & $(0.387)$ & $(0.220)$ \\
\hline \multirow[t]{2}{*}{ Median Income } & $0.000^{* * *}$ & $0.000^{* * *}$ & $0.000^{* * *}$ & $0.000^{*}$ \\
\hline & $(0.000)$ & $(0.000)$ & $(0.000)$ & $(0.000)$ \\
\hline \multirow[t]{2}{*}{ Pct. Below 12th Grade Education } & $0.130^{*}$ & $0.196^{* * *}$ & 0.093 & 0.011 \\
\hline & $(0.060)$ & $(0.058)$ & $(0.075)$ & $(0.046)$ \\
\hline \multirow[t]{2}{*}{ Constant } & $61.935^{* * *}$ & $41.391^{* * *}$ & $28.413^{* * *}$ & $62.405^{* * *}$ \\
\hline & $(5.552)$ & $(5.640)$ & $(7.389)$ & $(4.139)$ \\
\hline Observations & 158 & 158 & 158 & 158 \\
\hline$R^{2}$ & 0.353 & 0.424 & 0.367 & 0.256 \\
\hline
\end{tabular}

Standard errors in parentheses

${ }^{+} p<0.1,{ }^{*} p<0.05,{ }^{* *} p<0.01,{ }^{* * *} p<0.001$ 
Table 5: OLS Regression: Public Risk Perceptions.

\begin{tabular}{|c|c|c|c|c|c|c|c|}
\hline & $\begin{array}{l}\text { Worried } \\
\end{array}$ & Personal Harm & Harm US & $\begin{array}{l}\text { Harm Developing Countries } \\
\end{array}$ & Harm Future Generations & 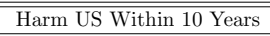 & \begin{tabular}{c|c|} 
Harm Plants and Animals \\
\end{tabular} \\
\hline Flood Sensitivity & $14.886^{* * *}$ & $8.686^{* *}$ & $11.918^{* * *}$ & $13.329^{* * *}$ & $12.395^{* * *}$ & $10.433^{* * *}$ & $13.362^{* * *}$ \\
\hline & $(3.351)$ & $(2.994)$ & $(2.781)$ & $(2.905)$ & $(2.529)$ & $(2.992)$ & $(2.757)$ \\
\hline Flood Damage (Log) & $-0.190^{+}$ & $-0.195^{*}$ & $-0.199^{*}$ & $-0.187^{*}$ & $-0.156^{+}$ & $-0.170^{+}$ & $-0.187^{+}$ \\
\hline & $(0.109)$ & $(0.096)$ & $(0.091)$ & $(0.095)$ & $(0.087)$ & $(0.094)$ & $(0.100)$ \\
\hline Flood Exposure & $\begin{array}{l}1.099 \\
(1.351)\end{array}$ & $\begin{array}{l}2.061^{+} \\
(1.128)\end{array}$ & $\begin{array}{r}0.656 \\
(1085)\end{array}$ & $\begin{array}{l}1.276 \\
(1.112)\end{array}$ & $\begin{array}{r}0.507 \\
(1.059)\end{array}$ & $\begin{array}{l}2.304^{*} \\
(1.161)\end{array}$ & $\begin{array}{l}0.512 \\
(1.125)\end{array}$ \\
\hline Flood Adaptive Capacity & $-3.331^{+}$ & $-4.893^{* *}$ & $-3.674^{*}$ & $\begin{array}{l}\left(1.11282^{+}\right. \\
-3\end{array}$ & -1.449 & $-3.775^{*}$ & $\begin{array}{l}(1.125) \\
-0.791\end{array}$ \\
\hline & $(2.003)$ & $(1.601)$ & (1.579) & (1.693) & $(1.602)$ & (1.694) & $\begin{array}{l}-0.151 \\
(1.711)\end{array}$ \\
\hline Flood Social Readiness & 2.171 & $\begin{array}{l}-1.422 \\
-1687\end{array}$ & 1.663 & $\begin{array}{r}2.849 \\
\end{array}$ & $2.913^{+}$ & 1.463 & $3.723^{*}$ \\
\hline Flood Economic Readiness & 1.779 & $\begin{array}{c}(1.687) \\
0.639\end{array}$ & $\begin{array}{c}(1.673) \\
1.099\end{array}$ & $\begin{array}{c}(1.735) \\
2.524\end{array}$ & $\begin{array}{c}(1.526) \\
1.590\end{array}$ & $\begin{array}{c}(1.763) \\
1.186\end{array}$ & $\begin{array}{c}(1.617) \\
1.445\end{array}$ \\
\hline & $(1.927)$ & $\begin{array}{l}0.059 \\
(1.554)\end{array}$ & $\begin{array}{l}1.099 \\
(1.509)\end{array}$ & $\begin{array}{l}2.024 \\
(1.602)\end{array}$ & $\begin{array}{l}1.090 \\
(1.534)\end{array}$ & $\begin{array}{l}1.186 \\
(1.482)\end{array}$ & $\begin{array}{l}1.445 \\
(1.688)\end{array}$ \\
\hline Trump Vote 2016 & $\begin{array}{l}-7.860^{*} \\
(3.682)\end{array}$ & $\begin{array}{r}-7.794^{* *} \\
(2.650)\end{array}$ & $\begin{array}{l}-6.524^{*} \\
(2.704)\end{array}$ & $\begin{array}{l}-5.943^{+} \\
(3.015)\end{array}$ & $\begin{array}{l}-3.879 \\
(3.137)\end{array}$ & $\begin{array}{c}-9.445^{* * *} \\
(2.782)\end{array}$ & $\begin{array}{l}-4.994 \\
(3.108)\end{array}$ \\
\hline Total Population (Log) & -0.347 & $\begin{array}{l}-0.444 \\
(0.300)\end{array}$ & $\begin{array}{l}-0.338 \\
(0.297)\end{array}$ & $\begin{array}{l}-0.254 \\
(0.308)\end{array}$ & -0.117 & $\begin{array}{l}-0.318 \\
-0.098\end{array}$ & -0.149 \\
\hline Median Income & $\begin{array}{c}(0.422) \\
0.000^{* * *} \\
(0.000)\end{array}$ & $\begin{array}{c}(0.300) \\
0.000^{* * *} \\
(0.000)\end{array}$ & $\begin{array}{c}(0.297) \\
0.000^{* * *} \\
(0.000)\end{array}$ & $\begin{array}{c}(0.308) \\
0.000^{* * *} \\
(0.000)\end{array}$ & $\begin{array}{c}(0.297) \\
0.000^{* * *} \\
(0.000)\end{array}$ & $\begin{array}{c}(0.298) \\
0.000^{* * *} \\
(0.000)\end{array}$ & $\begin{array}{c}(0.316) \\
0.000^{* * *} \\
(0.000)\end{array}$ \\
\hline Pct. Below 12th Grade Education & $\begin{array}{c}0.253^{* * *} \\
(0.075)\end{array}$ & $\begin{array}{c}0.303^{* * *} \\
(0.057)\end{array}$ & $\begin{array}{c}0.226^{* * *} \\
(0.059)\end{array}$ & $\begin{array}{c}0.210^{* * *} \\
(0.061)\end{array}$ & $\begin{array}{l}0.164^{* *} \\
(0.056)\end{array}$ & $\begin{array}{l}0.203^{* *} \\
(0.064)\end{array}$ & $\begin{array}{l}0.168^{* *} \\
(0.060)\end{array}$ \\
\hline Constant & $\begin{array}{c}44.898^{* * *} * \\
(7.328)\end{array}$ & $\begin{array}{c}34.508^{* * * *} \\
(5.456)\end{array}$ & $\begin{array}{c}48.998^{* * * *} \\
(5.300)\end{array}$ & $\begin{array}{c}50.631^{* * * *} \\
(5.680)\end{array}$ & $\begin{array}{c}56.844^{* * *} \\
(5.310)\end{array}$ & $\begin{array}{c}44.100^{* * *} \\
(5.573)\end{array}$ & $\begin{array}{c}55.789^{* * * *} \\
(5.524)\end{array}$ \\
\hline Observations & 158 & 158 & 158 & 158 & 158 & 158 & 158 \\
\hline$R^{2}$ & 0.427 & 0.531 & 0.470 & 0.449 & 0.394 & 0.423 & 0.394 \\
\hline
\end{tabular}

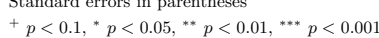


Table 6: OLS Regression: Public Support for Climate Action.

\begin{tabular}{|c|c|c|c|c|}
\hline & $\begin{array}{c}(1) \\
\text { CO2 Limits }\end{array}$ & $\begin{array}{c}(2) \\
\text { Regulate } \mathrm{CO} 2\end{array}$ & $\begin{array}{l}(3) \\
20 \% \text { Electricity from Renewables }\end{array}$ & $\begin{array}{c}\text { (4) } \\
\text { Fund Renewables }\end{array}$ \\
\hline Flood Sensitivity & $\begin{array}{c}13.783^{* * *} \\
(3.196)\end{array}$ & $\begin{array}{l}9.519^{* * *} \\
(2.290)\end{array}$ & $\begin{array}{c}8.480^{* * *} \\
(2.060)\end{array}$ & $\begin{array}{l}5.735^{* * *} \\
(1.685)\end{array}$ \\
\hline Flood Damage (Log) & $\begin{array}{l}-0.152 \\
(0.106)\end{array}$ & $\begin{array}{l}-0.105 \\
(0.069)\end{array}$ & $\begin{array}{l}-0.104 \\
(0.067)\end{array}$ & $\begin{array}{l}-0.054 \\
(0.054)\end{array}$ \\
\hline Flood Exposure & $\begin{array}{l}-0.127 \\
(1.404)\end{array}$ & $\begin{array}{c}0.215 \\
(0.915)\end{array}$ & $\begin{array}{c}0.911 \\
(0.843)\end{array}$ & $\begin{array}{l}-0.386 \\
(0.590)\end{array}$ \\
\hline Flood Adaptive Capacity & $\begin{array}{l}-2.252 \\
(2.072)\end{array}$ & $\begin{array}{c}0.820 \\
(1.339)\end{array}$ & $\begin{array}{l}-0.845 \\
(1.313)\end{array}$ & $\begin{array}{l}1.046 \\
(0.911)\end{array}$ \\
\hline Flood Social Readiness & $\begin{array}{l}4.176^{*} \\
(1.962)\end{array}$ & $\begin{array}{l}2.997^{*} \\
(1.260)\end{array}$ & $\begin{array}{l}3.439^{* *} \\
(1.244)\end{array}$ & $\begin{array}{l}2.883^{* *} \\
(0.889)\end{array}$ \\
\hline Flood Economic Readiness & $\begin{array}{l}1.337 \\
(1.982)\end{array}$ & $\begin{array}{l}1.322 \\
(1.254)\end{array}$ & $\begin{array}{l}1.479 \\
(1.219)\end{array}$ & $\begin{array}{l}1.595^{+} \\
(0.935)\end{array}$ \\
\hline Trump Vote 2016 & $\begin{array}{l}-3.952 \\
(3.561)\end{array}$ & $\begin{array}{l}-0.416 \\
(2.316)\end{array}$ & $\begin{array}{l}-4.003 \\
(2.423)\end{array}$ & $\begin{array}{c}0.683 \\
(1.801)\end{array}$ \\
\hline Total Population (Log) & $\begin{array}{c}0.093 \\
(0.380)\end{array}$ & $\begin{array}{c}0.246 \\
(0.233)\end{array}$ & $\begin{array}{c}0.089 \\
(0.219)\end{array}$ & $\begin{array}{c}0.247 \\
(0.163)\end{array}$ \\
\hline Median Income & $\begin{array}{c}0.000^{* * *} \\
(0.000)\end{array}$ & $\begin{array}{l}0.000^{*} \\
(0.000)\end{array}$ & $\begin{array}{c}0.000^{* * *} \\
(0.000)\end{array}$ & $\begin{array}{l}0.000 \\
(0.000)\end{array}$ \\
\hline Pct. Below 12th Grade Education & $\begin{array}{l}0.166^{*} \\
(0.067)\end{array}$ & $\begin{array}{c}0.031 \\
(0.045)\end{array}$ & $\begin{array}{c}0.047 \\
(0.041)\end{array}$ & $\begin{array}{l}-0.029 \\
(0.033)\end{array}$ \\
\hline Constant & $\begin{array}{c}52.580^{* * *} \\
(6.812)\end{array}$ & $\begin{array}{c}62.110^{* * *} \\
(4.341)\end{array}$ & $\begin{array}{c}56.431^{* * *} \\
(4.167)\end{array}$ & $\begin{array}{c}72.747^{* * *} \\
(3.036)\end{array}$ \\
\hline Observations & 158 & 158 & 158 & 158 \\
\hline$R^{2}$ & 0.356 & 0.260 & 0.336 & 0.281 \\
\hline
\end{tabular}

Standard errors in parentheses

${ }^{+} p<0.1,{ }^{*} p<0.05,{ }^{* *} p<0.01,{ }^{* * *} p<0.001$ 


\section{B.2 Public Beliefs about Climate Change}

Table 7: OLS Regression: Estimated percentage who think that global warming is happening.

\begin{tabular}{|c|c|c|c|c|}
\hline & $(1)$ & $(2)$ & $(3)$ & $(4)$ \\
\hline Flood Sensitivity & $\begin{array}{c}2.232 \\
(1.870)\end{array}$ & $\begin{array}{c}2.515 \\
(2.003)\end{array}$ & $\begin{array}{l}4.763^{*} \\
(2.116)\end{array}$ & $\begin{array}{c}9.806^{* * *} \\
(2.846)\end{array}$ \\
\hline Flood Damage (Log) & & $\begin{array}{c}-0.343^{* *} \\
(0.106)\end{array}$ & $\begin{array}{c}-0.285^{* *} \\
(0.104)\end{array}$ & $\begin{array}{l}-0.199^{*} \\
(0.091)\end{array}$ \\
\hline Flood Exposure & & & $\begin{array}{l}-0.117 \\
(1.377)\end{array}$ & $\begin{array}{c}0.714 \\
(1.183)\end{array}$ \\
\hline Flood Adaptive Capacity & & & $\begin{array}{c}-4.646^{* *} \\
(1.620)\end{array}$ & $\begin{array}{l}-2.180 \\
(1.678)\end{array}$ \\
\hline Flood Social Readiness & & & $\begin{array}{l}3.711^{*} \\
(1.694)\end{array}$ & $\begin{array}{c}2.190 \\
(1.698)\end{array}$ \\
\hline Flood Economic Readiness & & & $\begin{array}{c}2.405 \\
(1.692)\end{array}$ & $\begin{array}{c}2.244 \\
(1.533)\end{array}$ \\
\hline Trump Vote 2016 & & & & $\begin{array}{l}-6.532^{*} \\
(3.244)\end{array}$ \\
\hline Total Population (Log) & & & & $\begin{array}{l}-0.174 \\
(0.307)\end{array}$ \\
\hline Median Income & & & & $\begin{array}{c}0.000^{* * *} \\
(0.000)\end{array}$ \\
\hline Pct. Below 12th Grade Education & & & & $\begin{array}{l}0.130^{*} \\
(0.060)\end{array}$ \\
\hline Constant & $\begin{array}{c}70.399^{* * *} \\
(0.916)\end{array}$ & $\begin{array}{c}73.986^{* * *} \\
(1.679)\end{array}$ & $\begin{array}{c}72.309^{* * *} \\
(2.107)\end{array}$ & $\begin{array}{c}61.935^{* * *} \\
(5.552)\end{array}$ \\
\hline Observations & 218 & 158 & 158 & 158 \\
\hline$R^{2}$ & 0.004 & 0.074 & 0.137 & 0.353 \\
\hline
\end{tabular}

Standard errors in parentheses

${ }^{+} p<0.1,{ }^{*} p<0.05,{ }^{* *} p<0.01,{ }^{* * *} p<0.001$ 
Table 8: OLS Regression: Estimated percentage who think that global warming is caused mostly by human activities.

\begin{tabular}{|c|c|c|c|c|}
\hline & (1) & $(2)$ & $(3)$ & $(4)$ \\
\hline Flood Sensitivity & $\begin{array}{l}3.453^{+} \\
(1.916)\end{array}$ & $\begin{array}{l}3.461^{+} \\
(2.052)\end{array}$ & $\begin{array}{l}5.950^{* *} \\
(2.149)\end{array}$ & $\begin{array}{c}10.850^{* * *} \\
(2.639)\end{array}$ \\
\hline Flood Damage (Log) & & $\begin{array}{c}-0.352^{* *} \\
(0.109)\end{array}$ & $\begin{array}{c}-0.288^{*} \\
(0.112)\end{array}$ & $\begin{array}{l}-0.188^{*} \\
(0.095)\end{array}$ \\
\hline Flood Exposure & & & $\begin{array}{l}-0.556 \\
(1.399)\end{array}$ & $\begin{array}{c}0.410 \\
(1.154)\end{array}$ \\
\hline Flood Adaptive Capacity & & & $\begin{array}{c}-5.321^{* *} \\
(1.711)\end{array}$ & $\begin{array}{l}-1.989 \\
(1.682)\end{array}$ \\
\hline Flood Social Readiness & & & $\begin{array}{l}3.908^{*} \\
(1.778)\end{array}$ & $\begin{array}{c}2.532 \\
(1.698)\end{array}$ \\
\hline Flood Economic Readiness & & & $\begin{array}{c}2.249 \\
(1.965)\end{array}$ & $\begin{array}{c}2.265 \\
(1.670)\end{array}$ \\
\hline Trump Vote 2016 & & & & $\begin{array}{c}-6.375^{+} \\
(3.263)\end{array}$ \\
\hline Total Population (Log) & & & & $\begin{array}{l}-0.128 \\
(0.319)\end{array}$ \\
\hline Median Income & & & & $\begin{array}{c}0.000^{* * *} \\
(0.000)\end{array}$ \\
\hline Pct. Below 12th Grade Education & & & & $\begin{array}{c}0.196^{* * *} \\
(0.058)\end{array}$ \\
\hline Constant & $\begin{array}{c}52.970^{* * *} \\
(0.942)\end{array}$ & $\begin{array}{c}56.713^{* * *} \\
(1.687)\end{array}$ & $\begin{array}{c}55.397^{* * *} \\
(2.284) \\
\end{array}$ & $\begin{array}{c}41.391^{* * *} \\
(5.640)\end{array}$ \\
\hline Observations & 218 & 158 & 158 & 158 \\
\hline$R^{2}$ & 0.010 & 0.078 & 0.147 & 0.424 \\
\hline
\end{tabular}

Standard errors in parentheses

${ }^{+} p<0.1,{ }^{*} p<0.05,{ }^{* *} p<0.01,{ }^{* * *} p<0.001$ 
Table 9: OLS Regression: Estimated percentage who believe that most scientists think global warming is happening.

\begin{tabular}{|c|c|c|c|c|}
\hline & (1) & $(2)$ & $(3)$ & $(4)$ \\
\hline Flood Sensitivity & $\begin{array}{l}6.660^{*} \\
(2.886)\end{array}$ & $\begin{array}{l}7.971^{*} \\
(3.115)\end{array}$ & $\begin{array}{c}11.091^{* * *} \\
(3.279)\end{array}$ & $\begin{array}{c}21.056^{* * *} \\
(4.058)\end{array}$ \\
\hline Flood Damage (Log) & & $\begin{array}{c}-0.496^{* *} \\
(0.152)\end{array}$ & $\begin{array}{c}-0.401^{*} \\
(0.154)\end{array}$ & $\begin{array}{c}-0.261^{+} \\
(0.140)\end{array}$ \\
\hline Flood Exposure & & & $\begin{array}{c}-0.444 \\
(1.800)\end{array}$ & $\begin{array}{c}0.585 \\
(1.546)\end{array}$ \\
\hline Flood Adaptive Capacity & & & $\begin{array}{l}-4.322^{*} \\
(2.169)\end{array}$ & $\begin{array}{l}-2.098 \\
(2.332)\end{array}$ \\
\hline Flood Social Readiness & & & $\begin{array}{c}8.914^{* * *} \\
(2.387)\end{array}$ & $\begin{array}{l}5.884^{*} \\
(2.392)\end{array}$ \\
\hline Flood Economic Readiness & & & $\begin{array}{c}2.505 \\
(2.666)\end{array}$ & $\begin{array}{c}2.187 \\
(2.441)\end{array}$ \\
\hline Trump Vote 2016 & & & & $\begin{array}{l}-3.884 \\
(4.009)\end{array}$ \\
\hline Total Population (Log) & & & & $\begin{array}{c}0.061 \\
(0.387)\end{array}$ \\
\hline Median Income & & & & $\begin{array}{c}0.000^{* * *} \\
(0.000)\end{array}$ \\
\hline Pct. Below 12th Grade Education & & & & $\begin{array}{c}0.093 \\
(0.075)\end{array}$ \\
\hline Constant & $\begin{array}{c}47.792^{* * *} \\
(1.430)\end{array}$ & $\begin{array}{c}52.492^{* * *} \\
(2.506)\end{array}$ & $\begin{array}{c}47.798^{* * *} \\
(3.135)\end{array}$ & $\begin{array}{c}28.413^{* * *} \\
(7.389)\end{array}$ \\
\hline Observations & 218 & 158 & 158 & 158 \\
\hline$R^{2}$ & 0.018 & 0.100 & 0.186 & 0.367 \\
\hline
\end{tabular}

Standard errors in parentheses

${ }^{+} p<0.1,{ }^{*} p<0.05,{ }^{* *} p<0.01,{ }^{* * *} p<0.001$ 
Table 10: OLS Regression: Estimated percentage who somewhat or strongly trust climate scientists as a source of information about global warming.

\begin{tabular}{|c|c|c|c|c|}
\hline & (1) & $(2)$ & $(3)$ & $(4)$ \\
\hline Flood Sensitivity & $\begin{array}{c}1.040 \\
(1.284)\end{array}$ & $\begin{array}{c}0.919 \\
(1.548)\end{array}$ & $\begin{array}{c}2.337 \\
(1.618)\end{array}$ & $\begin{array}{l}4.913^{*} \\
(2.187)\end{array}$ \\
\hline Flood Damage (Log) & & $\begin{array}{c}-0.243^{* * *} \\
(0.072)\end{array}$ & $\begin{array}{c}-0.205^{* *} \\
(0.068)\end{array}$ & $\begin{array}{l}-0.159^{*} \\
(0.066)\end{array}$ \\
\hline Flood Exposure & & & $\begin{array}{l}-0.198 \\
(1.028)\end{array}$ & $\begin{array}{c}0.046 \\
(0.972)\end{array}$ \\
\hline Flood Adaptive Capacity & & & $\begin{array}{l}-1.946 \\
(1.218)\end{array}$ & $\begin{array}{l}-0.781 \\
(1.406)\end{array}$ \\
\hline Flood Social Readiness & & & $\begin{array}{l}4.128^{* *} \\
(1.323)\end{array}$ & $\begin{array}{l}2.975^{*} \\
(1.383)\end{array}$ \\
\hline Flood Economic Readiness & & & $\begin{array}{c}1.922 \\
(1.289)\end{array}$ & $\begin{array}{c}1.719 \\
(1.246)\end{array}$ \\
\hline Trump Vote 2016 & & & & $\begin{array}{l}-1.636 \\
(2.206)\end{array}$ \\
\hline Total Population (Log) & & & & $\begin{array}{c}0.333 \\
(0.220)\end{array}$ \\
\hline Median Income & & & & $\begin{array}{l}0.000^{*} \\
(0.000)\end{array}$ \\
\hline Pct. Below 12th Grade Education & & & & $\begin{array}{c}0.011 \\
(0.046)\end{array}$ \\
\hline Constant & $\begin{array}{c}71.747^{* * *} \\
(0.655)\end{array}$ & $\begin{array}{c}74.694^{* * *} \\
(1.201)\end{array}$ & $\begin{array}{c}72.186^{* * *} \\
(1.584)\end{array}$ & $\begin{array}{c}62.405^{* * *} \\
(4.139)\end{array}$ \\
\hline Observations & 218 & 158 & 158 & 158 \\
\hline$R^{2}$ & 0.002 & 0.060 & 0.137 & 0.256 \\
\hline
\end{tabular}

Standard errors in parentheses

${ }^{+} p<0.1,{ }^{*} p<0.05,{ }^{* *} p<0.01,{ }^{* * *} p<0.001$ 


\section{B.3 Public Risk Perceptions about Climate Change}

Table 11: OLS Regression: Estimated percentage who are somewhat/very worried about global warming.

\begin{tabular}{|c|c|c|c|c|}
\hline & $(1)$ & $(2)$ & $(3)$ & $(4)$ \\
\hline Flood Sensitivity & $\begin{array}{l}5.509^{*} \\
(2.596)\end{array}$ & $\begin{array}{l}4.917^{+} \\
(2.680)\end{array}$ & $\begin{array}{l}8.073^{* *} \\
(2.855)\end{array}$ & $\begin{array}{c}14.886^{* * *} \\
(3.351)\end{array}$ \\
\hline Flood Damage (Log) & & $\begin{array}{c}-0.405^{* *} \\
(0.128)\end{array}$ & $\begin{array}{l}-0.318^{*} \\
(0.132)\end{array}$ & $\begin{array}{r}-0.190^{+} \\
(0.109)\end{array}$ \\
\hline Flood Exposure & & & $\begin{array}{l}-0.182 \\
(1.675)\end{array}$ & $\begin{array}{c}1.099 \\
(1.351)\end{array}$ \\
\hline Flood Adaptive Capacity & & & $\begin{array}{c}-7.222^{* *} \\
(2.179)\end{array}$ & $\begin{array}{c}-3.331^{+} \\
(2.003)\end{array}$ \\
\hline Flood Social Readiness & & & $\begin{array}{l}3.890^{+} \\
(2.310)\end{array}$ & $\begin{array}{c}2.171 \\
(2.105)\end{array}$ \\
\hline Flood Economic Readiness & & & $\begin{array}{l}1.723 \\
(2.324)\end{array}$ & $\begin{array}{c}1.779 \\
(1.927)\end{array}$ \\
\hline Trump Vote 2016 & & & & $\begin{array}{l}-7.860^{*} \\
(3.682)\end{array}$ \\
\hline Total Population (Log) & & & & $\begin{array}{l}-0.347 \\
(0.422)\end{array}$ \\
\hline Median Income & & & & $\begin{array}{c}0.000^{* * *} \\
(0.000)\end{array}$ \\
\hline Pct. Below 12th Grade Education & & & & $\begin{array}{c}0.253^{* * *} \\
(0.075)\end{array}$ \\
\hline Constant & $\begin{array}{c}56.846^{* * *} \\
(1.226)\end{array}$ & $\begin{array}{c}61.275^{* * *} \\
(2.066)\end{array}$ & $\begin{array}{c}60.591^{* * *} \\
(2.859)\end{array}$ & $\begin{array}{c}44.898^{* * *} \\
(7.328)\end{array}$ \\
\hline Observations & 218 & 158 & 158 & 158 \\
\hline$R^{2}$ & 0.016 & 0.076 & 0.142 & 0.427 \\
\hline
\end{tabular}


Table 12: OLS Regression: Estimated percentage who think global warming will harm them personally a moderate amount/a great deal.

\begin{tabular}{|c|c|c|c|c|}
\hline & 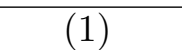 & $\overline{(2)}$ & $\overline{(3)}$ & $\overline{(4)}$ \\
\hline Flood Sensitivity & $\begin{array}{c}2.988 \\
(2.342)\end{array}$ & $\begin{array}{c}1.571 \\
(2.357)\end{array}$ & $\begin{array}{l}4.562^{+} \\
(2.391)\end{array}$ & $\begin{array}{l}8.686^{* *} \\
(2.994)\end{array}$ \\
\hline Flood Damage (Log) & & $\begin{array}{c}-0.383^{* *} \\
(0.116)\end{array}$ & $\begin{array}{c}-0.300^{*} \\
(0.115)\end{array}$ & $\begin{array}{l}-0.195^{*} \\
(0.096)\end{array}$ \\
\hline Flood Exposure & & & $\begin{array}{c}0.859 \\
(1.431)\end{array}$ & $\begin{array}{l}2.061^{+} \\
(1.128)\end{array}$ \\
\hline Flood Adaptive Capacity & & & $\begin{array}{c}-9.094^{* * *} \\
(1.975)\end{array}$ & $\begin{array}{c}-4.893^{* *} \\
(1.601)\end{array}$ \\
\hline Flood Social Readiness & & & $\begin{array}{l}-0.674 \\
(2.032)\end{array}$ & $\begin{array}{l}-1.422 \\
(1.687)\end{array}$ \\
\hline Flood Economic Readiness & & & $\begin{array}{c}0.343 \\
(2.040)\end{array}$ & $\begin{array}{c}0.639 \\
(1.554)\end{array}$ \\
\hline Trump Vote 2016 & & & & $\begin{array}{c}-7.794^{* *} \\
(2.650)\end{array}$ \\
\hline Total Population (Log) & & & & $\begin{array}{l}-0.444 \\
(0.300)\end{array}$ \\
\hline Median Income & & & & $\begin{array}{c}0.000^{* * *} \\
(0.000)\end{array}$ \\
\hline Pct. Below 12th Grade Education & & & & $\begin{array}{c}0.303^{* * *} \\
(0.057)\end{array}$ \\
\hline Constant & $\begin{array}{c}39.913^{* * *} \\
(1.096)\end{array}$ & $\begin{array}{c}44.501^{* * *} \\
(1.803)\end{array}$ & $\begin{array}{c}47.126^{* * *} \\
(2.563)\end{array}$ & $\begin{array}{c}34.508^{* * *} \\
(5.456)\end{array}$ \\
\hline Observations & 218 & 158 & 158 & 158 \\
\hline$R^{2}$ & 0.006 & 0.071 & 0.212 & 0.531 \\
\hline
\end{tabular}

Standard errors in parentheses

${ }^{+} p<0.1,{ }^{*} p<0.05,{ }^{* *} p<0.01,{ }^{* * *} p<0.001$ 
Table 13: OLS Regression: Estimated percentage who think global warming will harm people in the US a moderate amount/a great deal.

\begin{tabular}{|c|c|c|c|c|}
\hline & (1) & $(2)$ & $(3)$ & $(4)$ \\
\hline Flood Sensitivity & $\begin{array}{l}4.111^{+} \\
(2.144)\end{array}$ & $\begin{array}{c}3.532 \\
(2.139)\end{array}$ & $\begin{array}{l}6.426^{* *} \\
(2.276)\end{array}$ & $\begin{array}{c}11.918^{* * *} \\
(2.781)\end{array}$ \\
\hline Flood Damage (Log) & & $\begin{array}{c}-0.385^{* * *} \\
(0.107)\end{array}$ & $\begin{array}{c}-0.305^{* *} \\
(0.108)\end{array}$ & $\begin{array}{l}-0.199^{*} \\
(0.091)\end{array}$ \\
\hline Flood Exposure & & & $\begin{array}{l}-0.433 \\
(1.356)\end{array}$ & $\begin{array}{c}0.656 \\
(1.085)\end{array}$ \\
\hline Flood Adaptive Capacity & & & $\begin{array}{c}-6.994^{* * *} \\
(1.758)\end{array}$ & $\begin{array}{l}-3.674^{*} \\
(1.579)\end{array}$ \\
\hline Flood Social Readiness & & & $\begin{array}{c}2.963 \\
(1.881)\end{array}$ & $\begin{array}{c}1.663 \\
(1.673)\end{array}$ \\
\hline Flood Economic Readiness & & & $\begin{array}{c}0.997 \\
(1.876)\end{array}$ & $\begin{array}{c}1.099 \\
(1.509)\end{array}$ \\
\hline Trump Vote 2016 & & & & $\begin{array}{l}-6.524^{*} \\
(2.704)\end{array}$ \\
\hline Total Population (Log) & & & & $\begin{array}{l}-0.338 \\
(0.297)\end{array}$ \\
\hline Median Income & & & & $\begin{array}{c}0.000^{* * *} \\
(0.000)\end{array}$ \\
\hline Pct. Below 12th Grade Education & & & & $\begin{array}{c}0.226^{* * *} \\
(0.059)\end{array}$ \\
\hline Constant & $\begin{array}{c}57.194^{* * *} \\
(1.031)\end{array}$ & $\begin{array}{c}61.498^{* * *} \\
(1.702)\end{array}$ & $\begin{array}{c}61.701^{* * *} \\
(2.280)\end{array}$ & $\begin{array}{c}48.998^{* * *} \\
(5.300)\end{array}$ \\
\hline Observations & 218 & 158 & 158 & 158 \\
\hline$R^{2}$ & 0.012 & 0.091 & 0.175 & 0.470 \\
\hline
\end{tabular}

Standard errors in parentheses

${ }^{+} p<0.1,{ }^{*} p<0.05,{ }^{* *} p<0.01,{ }^{* * *} p<0.001$ 
Table 14: OLS Regression: Estimated percentage who think global warming will harm people in developing countries a moderate amount/a great deal.

\begin{tabular}{|c|c|c|c|c|}
\hline & (1) & $(2)$ & $(3)$ & $(4)$ \\
\hline Flood Sensitivity & $\begin{array}{l}4.477^{*} \\
(2.120)\end{array}$ & $\begin{array}{l}4.546^{*} \\
(2.172)\end{array}$ & $\begin{array}{l}7.552^{* *} \\
(2.269)\end{array}$ & $\begin{array}{c}13.329^{* * *} \\
(2.905)\end{array}$ \\
\hline Flood Damage (Log) & & $\begin{array}{c}-0.378^{* * *} \\
(0.109)\end{array}$ & $\begin{array}{c}-0.296^{* *} \\
(0.111)\end{array}$ & $\begin{array}{l}-0.187^{*} \\
(0.095)\end{array}$ \\
\hline Flood Exposure & & & $\begin{array}{c}0.220 \\
(1.375)\end{array}$ & $\begin{array}{c}1.276 \\
(1.112)\end{array}$ \\
\hline Flood Adaptive Capacity & & & $\begin{array}{c}-6.494^{* * *} \\
(1.747)\end{array}$ & $\begin{array}{c}-3.282^{+} \\
(1.693)\end{array}$ \\
\hline Flood Social Readiness & & & $\begin{array}{l}4.298^{*} \\
(1.859)\end{array}$ & $\begin{array}{c}2.849 \\
(1.735)\end{array}$ \\
\hline Flood Economic Readiness & & & $\begin{array}{c}2.455 \\
(1.921)\end{array}$ & $\begin{array}{c}2.524 \\
(1.602)\end{array}$ \\
\hline Trump Vote 2016 & & & & $\begin{array}{r}-5.943^{+} \\
(3.015)\end{array}$ \\
\hline Total Population (Log) & & & & $\begin{array}{l}-0.254 \\
(0.308)\end{array}$ \\
\hline Median Income & & & & $\begin{array}{c}0.000^{* * *} \\
(0.000)\end{array}$ \\
\hline Pct. Below 12th Grade Education & & & & $\begin{array}{c}0.210^{* * *} \\
(0.061)\end{array}$ \\
\hline Constant & $\begin{array}{c}62.137^{* * *} \\
(1.021)\end{array}$ & $\begin{array}{c}66.025^{* * *} \\
(1.702)\end{array}$ & $\begin{array}{c}64.391^{* * *} \\
(2.339)\end{array}$ & $\begin{array}{c}50.631^{* * *} \\
(5.680)\end{array}$ \\
\hline Observations & 218 & 158 & 158 & 158 \\
\hline$R^{2}$ & 0.014 & 0.091 & 0.178 & 0.449 \\
\hline
\end{tabular}

Standard errors in parentheses

${ }^{+} p<0.1,{ }^{*} p<0.05,{ }^{* *} p<0.01,{ }^{* * *} p<0.001$ 
Table 15: OLS Regression: Estimated percentage who think global warming will harm future generations a moderate amount/a great deal.

\begin{tabular}{|c|c|c|c|c|}
\hline & (1) & $(2)$ & $(3)$ & $(4)$ \\
\hline Flood Sensitivity & $\begin{array}{l}4.394^{*} \\
(1.795)\end{array}$ & $\begin{array}{l}4.822^{* *} \\
(1.837)\end{array}$ & $\begin{array}{c}6.974^{* * *} \\
(2.024)\end{array}$ & $\begin{array}{c}12.395^{* * *} \\
(2.529)\end{array}$ \\
\hline Flood Damage (Log) & & $\begin{array}{c}-0.314^{* *} \\
(0.094)\end{array}$ & $\begin{array}{c}-0.253^{*} \\
(0.100)\end{array}$ & $\begin{array}{c}-0.156^{+} \\
(0.087)\end{array}$ \\
\hline Flood Exposure & & & $\begin{array}{c}-0.362 \\
(1.257)\end{array}$ & $\begin{array}{c}0.507 \\
(1.059)\end{array}$ \\
\hline Flood Adaptive Capacity & & & $\begin{array}{l}-4.024^{*} \\
(1.593)\end{array}$ & $\begin{array}{l}-1.449 \\
(1.602)\end{array}$ \\
\hline Flood Social Readiness & & & $\begin{array}{l}4.324^{* *} \\
(1.624)\end{array}$ & $\begin{array}{l}2.913^{+} \\
(1.526)\end{array}$ \\
\hline Flood Economic Readiness & & & $\begin{array}{c}1.539 \\
(1.739)\end{array}$ & $\begin{array}{c}1.590 \\
(1.534)\end{array}$ \\
\hline Trump Vote 2016 & & & & $\begin{array}{l}-3.879 \\
(3.137)\end{array}$ \\
\hline Total Population (Log) & & & & $\begin{array}{l}-0.117 \\
(0.297)\end{array}$ \\
\hline Median Income & & & & $\begin{array}{c}0.000^{* * *} \\
(0.000)\end{array}$ \\
\hline Pct. Below 12th Grade Education & & & & $\begin{array}{l}0.164^{* *} \\
(0.056)\end{array}$ \\
\hline Constant & $\begin{array}{c}68.882^{* * *} \\
(0.889)\end{array}$ & $\begin{array}{c}71.939^{* * *} \\
(1.529)\end{array}$ & $\begin{array}{c}70.185^{* * *} \\
(2.116)\end{array}$ & $\begin{array}{c}56.844^{* * *} \\
(5.310)\end{array}$ \\
\hline Observations & 218 & 158 & 158 & 158 \\
\hline$R^{2}$ & 0.018 & 0.089 & 0.151 & 0.394 \\
\hline
\end{tabular}

Standard errors in parentheses

${ }^{+} p<0.1,{ }^{*} p<0.05,{ }^{* *} p<0.01,{ }^{* * *} p<0.001$ 
Table 16: OLS Regression: Estimated percentage who think global warming will start to harm people in the United States now/within 10 years.

\begin{tabular}{|c|c|c|c|c|}
\hline & (1) & $(2)$ & $(3)$ & $(4)$ \\
\hline Flood Sensitivity & $\begin{array}{l}3.902^{+} \\
(2.060)\end{array}$ & $\begin{array}{l}3.894^{+} \\
(2.184)\end{array}$ & $\begin{array}{l}6.895^{* *} \\
(2.294)\end{array}$ & $\begin{array}{c}10.433^{* * *} \\
(2.992)\end{array}$ \\
\hline Flood Damage (Log) & & $\begin{array}{c}-0.343^{* *} \\
(0.118)\end{array}$ & $\begin{array}{c}-0.252^{*} \\
(0.114)\end{array}$ & $\begin{array}{c}-0.170^{+} \\
(0.094)\end{array}$ \\
\hline Flood Exposure & & & $\begin{array}{c}1.337 \\
(1.398)\end{array}$ & $\begin{array}{l}2.304^{*} \\
(1.161)\end{array}$ \\
\hline Flood Adaptive Capacity & & & $\begin{array}{c}-7.261^{* * *} \\
(1.788)\end{array}$ & $\begin{array}{l}-3.775^{*} \\
(1.694)\end{array}$ \\
\hline Flood Social Readiness & & & $\begin{array}{c}2.489 \\
(1.936)\end{array}$ & $\begin{array}{c}1.463 \\
(1.763)\end{array}$ \\
\hline Flood Economic Readiness & & & $\begin{array}{c}1.242 \\
(1.766)\end{array}$ & $\begin{array}{c}1.186 \\
(1.482)\end{array}$ \\
\hline Trump Vote 2016 & & & & $\begin{array}{c}-9.445^{* * *} \\
(2.782)\end{array}$ \\
\hline Total Population (Log) & & & & $\begin{array}{l}-0.318 \\
(0.298)\end{array}$ \\
\hline Median Income & & & & $\begin{array}{c}0.000^{* * *} \\
(0.000)\end{array}$ \\
\hline Pct. Below 12th Grade Education & & & & $\begin{array}{l}0.203^{* *} \\
(0.064)\end{array}$ \\
\hline Constant & $\begin{array}{c}50.154^{* * *} \\
(1.000)\end{array}$ & $\begin{array}{c}53.802^{* * *} \\
(1.852)\end{array}$ & $\begin{array}{c}53.431^{* * *} \\
(2.403)\end{array}$ & $\begin{array}{c}44.100^{* * *} \\
(5.573)\end{array}$ \\
\hline Observations & 218 & 158 & 158 & 158 \\
\hline$R^{2}$ & 0.011 & 0.075 & 0.166 & 0.423 \\
\hline
\end{tabular}

Standard errors in parentheses

${ }^{+} p<0.1,{ }^{*} p<0.05,{ }^{* *} p<0.01,{ }^{* * *} p<0.001$ 
Table 17: OLS Regression: Estimated percentage who think global warming will harm plants and animal species a moderate amount/a great deal.

\begin{tabular}{|c|c|c|c|c|}
\hline & (1) & $(2)$ & $(3)$ & $(4)$ \\
\hline Flood Sensitivity & $\begin{array}{l}5.146^{* *} \\
(1.963)\end{array}$ & $\begin{array}{l}5.571^{* *} \\
(2.054)\end{array}$ & $\begin{array}{c}7.732^{* * *} \\
(2.267)\end{array}$ & $\begin{array}{c}13.362^{* * *} \\
(2.757)\end{array}$ \\
\hline Flood Damage (Log) & & $\begin{array}{c}-0.352^{* *} \\
(0.106)\end{array}$ & $\begin{array}{c}-0.288^{*} \\
(0.112)\end{array}$ & $\begin{array}{c}-0.187^{+} \\
(0.100)\end{array}$ \\
\hline Flood Exposure & & & $\begin{array}{l}-0.410 \\
(1.352)\end{array}$ & $\begin{array}{c}0.512 \\
(1.125)\end{array}$ \\
\hline Flood Adaptive Capacity & & & $\begin{array}{l}-3.536^{*} \\
(1.712)\end{array}$ & $\begin{array}{l}-0.791 \\
(1.711)\end{array}$ \\
\hline Flood Social Readiness & & & $\begin{array}{l}5.242^{* *} \\
(1.679)\end{array}$ & $\begin{array}{c}3.723^{*} \\
(1.617)\end{array}$ \\
\hline Flood Economic Readiness & & & $\begin{array}{c}1.448 \\
(1.897)\end{array}$ & $\begin{array}{c}1.445 \\
(1.688)\end{array}$ \\
\hline Trump Vote 2016 & & & & $\begin{array}{l}-4.994 \\
(3.108)\end{array}$ \\
\hline Total Population (Log) & & & & $\begin{array}{l}-0.149 \\
(0.316)\end{array}$ \\
\hline Median Income & & & & $\begin{array}{c}0.000^{* * *} \\
(0.000)\end{array}$ \\
\hline Pct. Below 12th Grade Education & & & & $\begin{array}{l}0.168^{* *} \\
(0.060)\end{array}$ \\
\hline Constant & $\begin{array}{c}67.962^{* * *} \\
(0.975)\end{array}$ & $\begin{array}{c}71.474^{* * *} \\
(1.749)\end{array}$ & $\begin{array}{c}69.097^{* * *} \\
(2.280)\end{array}$ & $\begin{array}{c}55.789^{* * *} \\
(5.524)\end{array}$ \\
\hline Observations & 218 & 158 & 158 & 158 \\
\hline$R^{2}$ & 0.022 & 0.097 & 0.160 & 0.394 \\
\hline
\end{tabular}

Standard errors in parentheses

${ }^{+} p<0.1,{ }^{*} p<0.05,{ }^{* *} p<0.01,{ }^{* * *} p<0.001$ 


\section{B.4 Public Support for Climate Action}

Table 18: OLS Regression: Estimated percentage who somewhat/strongly support setting strict limits on existing coal-fire power plants.

\begin{tabular}{|c|c|c|c|c|}
\hline & $(1)$ & $(2)$ & $(3)$ & $(4)$ \\
\hline Flood Sensitivity & $\begin{array}{l}5.889^{* *} \\
(2.225)\end{array}$ & $\begin{array}{l}5.210^{*} \\
(2.477)\end{array}$ & $\begin{array}{l}8.053^{* *} \\
(2.559)\end{array}$ & $\begin{array}{c}13.783^{* * *} \\
(3.196)\end{array}$ \\
\hline Flood Damage (Log) & & $\begin{array}{c}-0.343^{* *} \\
(0.117)\end{array}$ & $\begin{array}{l}-0.261^{*} \\
(0.121)\end{array}$ & $\begin{array}{l}-0.152 \\
(0.106)\end{array}$ \\
\hline Flood Exposure & & & $\begin{array}{l}-1.019 \\
(1.607)\end{array}$ & $\begin{array}{l}-0.127 \\
(1.404)\end{array}$ \\
\hline Flood Adaptive Capacity & & & $\begin{array}{c}-5.303^{* *} \\
(1.948)\end{array}$ & $\begin{array}{l}-2.252 \\
(2.072)\end{array}$ \\
\hline Flood Social Readiness & & & $\begin{array}{l}5.873^{* *} \\
(1.947)\end{array}$ & $\begin{array}{l}4.176^{*} \\
(1.962)\end{array}$ \\
\hline Flood Economic Readiness & & & $\begin{array}{l}1.330 \\
(2.187)\end{array}$ & $\begin{array}{c}1.337 \\
(1.982)\end{array}$ \\
\hline Trump Vote 2016 & & & & $\begin{array}{l}-3.952 \\
(3.561)\end{array}$ \\
\hline Total Population (Log) & & & & $\begin{array}{c}0.093 \\
(0.380)\end{array}$ \\
\hline Median Income & & & & $\begin{array}{c}0.000^{* * *} \\
(0.000)\end{array}$ \\
\hline Pct. Below 12th Grade Education & & & & $\begin{array}{c}0.166^{*} \\
(0.067)\end{array}$ \\
\hline Constant & $\begin{array}{c}67.895^{* * *} \\
(1.105)\end{array}$ & $\begin{array}{c}71.869^{* * *} \\
(2.034)\end{array}$ & $\begin{array}{c}69.999^{* * *} \\
(2.621)\end{array}$ & $\begin{array}{c}52.580^{* * *} \\
(6.812) \\
\end{array}$ \\
\hline Observations & 218 & 158 & 158 & 158 \\
\hline$R^{2}$ & 0.023 & 0.071 & 0.144 & 0.356 \\
\hline
\end{tabular}


Table 19: OLS Regression: Estimated percentage who somewhat/strongly support regulating CO2 as a pollutant.

\begin{tabular}{|c|c|c|c|c|}
\hline & (1) & $(2)$ & $(3)$ & $(4)$ \\
\hline Flood Sensitivity & $\begin{array}{c}5.616^{* * *} \\
(1.307)\end{array}$ & $\begin{array}{c}6.041^{* * *} \\
(1.590)\end{array}$ & $\begin{array}{c}6.859^{* * *} \\
(1.699)\end{array}$ & $\begin{array}{c}9.519^{* * *} \\
(2.290)\end{array}$ \\
\hline Flood Damage (Log) & & $\begin{array}{l}-0.178^{*} \\
(0.074)\end{array}$ & $\begin{array}{c}-0.153^{*} \\
(0.072)\end{array}$ & $\begin{array}{l}-0.105 \\
(0.069)\end{array}$ \\
\hline Flood Exposure & & & $\begin{array}{l}-0.053 \\
(0.964)\end{array}$ & $\begin{array}{c}0.215 \\
(0.915)\end{array}$ \\
\hline Flood Adaptive Capacity & & & $\begin{array}{l}-0.221 \\
(1.172)\end{array}$ & $\begin{array}{c}0.820 \\
(1.339)\end{array}$ \\
\hline Flood Social Readiness & & & $\begin{array}{l}3.958^{* *} \\
(1.207)\end{array}$ & $\begin{array}{l}2.997^{*} \\
(1.260)\end{array}$ \\
\hline Flood Economic Readiness & & & $\begin{array}{c}1.394 \\
(1.256)\end{array}$ & $\begin{array}{c}1.322 \\
(1.254)\end{array}$ \\
\hline Trump Vote 2016 & & & & $\begin{array}{l}-0.416 \\
(2.316)\end{array}$ \\
\hline Total Population (Log) & & & & $\begin{array}{c}0.246 \\
(0.233)\end{array}$ \\
\hline Median Income & & & & $\begin{array}{l}0.000^{*} \\
(0.000)\end{array}$ \\
\hline Pct. Below 12th Grade Education & & & & $\begin{array}{c}0.031 \\
(0.045)\end{array}$ \\
\hline Constant & $\begin{array}{c}72.422^{* * *} \\
(0.666)\end{array}$ & $\begin{array}{c}74.233^{* * *} \\
(1.261)\end{array}$ & $\begin{array}{c}71.446^{* * *} \\
(1.554)\end{array}$ & $\begin{array}{c}62.110^{* * *} \\
(4.341)\end{array}$ \\
\hline Observations & 218 & 158 & 158 & 158 \\
\hline$R^{2}$ & 0.058 & 0.102 & 0.171 & 0.260 \\
\hline
\end{tabular}

Standard errors in parentheses

${ }^{+} p<0.1,{ }^{*} p<0.05,{ }^{* *} p<0.01,{ }^{* * *} p<0.001$ 
Table 20: OLS Regression: Estimated percentage who somewhat/strongly support requiring utilities to produce $20 \%$ electricity from renewable sources.

\begin{tabular}{|c|c|c|c|c|}
\hline & (1) & $(2)$ & $(3)$ & $(4)$ \\
\hline Flood Sensitivity & $\begin{array}{l}2.961^{*} \\
(1.209)\end{array}$ & $\begin{array}{l}3.651^{*} \\
(1.407)\end{array}$ & $\begin{array}{c}5.349^{* * *} \\
(1.451)\end{array}$ & $\begin{array}{c}8.480^{* * *} \\
(2.060)\end{array}$ \\
\hline Flood Damage (Log) & & $\begin{array}{c}-0.210^{* *} \\
(0.076)\end{array}$ & $\begin{array}{c}-0.157^{*} \\
(0.072)\end{array}$ & $\begin{array}{l}-0.104 \\
(0.067)\end{array}$ \\
\hline Flood Exposure & & & $\begin{array}{c}0.480 \\
(0.949)\end{array}$ & $\begin{array}{c}0.911 \\
(0.843)\end{array}$ \\
\hline Flood Adaptive Capacity & & & $\begin{array}{l}-2.357^{*} \\
(1.149)\end{array}$ & $\begin{array}{l}-0.845 \\
(1.313)\end{array}$ \\
\hline Flood Social Readiness & & & $\begin{array}{c}4.632^{* * *} \\
(1.229)\end{array}$ & $\begin{array}{l}3.439^{* *} \\
(1.244)\end{array}$ \\
\hline Flood Economic Readiness & & & $\begin{array}{c}1.696 \\
(1.284)\end{array}$ & $\begin{array}{c}1.479 \\
(1.219)\end{array}$ \\
\hline Trump Vote 2016 & & & & $\begin{array}{l}-4.003 \\
(2.423)\end{array}$ \\
\hline Total Population (Log) & & & & $\begin{array}{c}0.089 \\
(0.219)\end{array}$ \\
\hline Median Income & & & & $\begin{array}{c}0.000^{* * *} \\
(0.000)\end{array}$ \\
\hline Pct. Below 12th Grade Education & & & & $\begin{array}{c}0.047 \\
(0.041)\end{array}$ \\
\hline Constant & $\begin{array}{c}65.522^{* * *} \\
(0.623)\end{array}$ & $\begin{array}{c}67.529^{* * *} \\
(1.182)\end{array}$ & $\begin{array}{c}64.628^{* * *} \\
(1.524)\end{array}$ & $\begin{array}{c}56.431^{* * *} \\
(4.167)\end{array}$ \\
\hline Observations & 218 & 158 & 158 & 158 \\
\hline$R^{2}$ & 0.015 & 0.073 & 0.168 & 0.336 \\
\hline
\end{tabular}

Standard errors in parentheses

${ }^{+} p<0.1,{ }^{*} p<0.05,{ }^{* *} p<0.01,{ }^{* * *} p<0.001$ 
Table 21: OLS Regression: Estimated percentage who somewhat/strongly support funding research into renewable energy sources.

\begin{tabular}{|c|c|c|c|c|}
\hline & $(1)$ & $\overline{(2)}$ & $(\overline{(3)}$ & $(4)$ \\
\hline Flood Sensitivity & $\begin{array}{l}2.147^{*} \\
(0.913)\end{array}$ & $\begin{array}{l}2.699^{*} \\
(1.109)\end{array}$ & $\begin{array}{l}3.086^{* *} \\
(1.160)\end{array}$ & $\begin{array}{c}5.735^{* * *} \\
(1.685)\end{array}$ \\
\hline Flood Damage (Log) & & $\begin{array}{l}-0.095 \\
(0.060)\end{array}$ & $\begin{array}{l}-0.086 \\
(0.055)\end{array}$ & $\begin{array}{l}-0.054 \\
(0.054)\end{array}$ \\
\hline Flood Exposure & & & $\begin{array}{l}-0.488 \\
(0.629)\end{array}$ & $\begin{array}{l}-0.386 \\
(0.590)\end{array}$ \\
\hline Flood Adaptive Capacity & & & $\begin{array}{c}0.915 \\
(0.792)\end{array}$ & $\begin{array}{c}1.046 \\
(0.911)\end{array}$ \\
\hline Flood Social Readiness & & & $\begin{array}{c}3.882^{* * *} \\
(0.829)\end{array}$ & $\begin{array}{l}2.883^{* *} \\
(0.889)\end{array}$ \\
\hline Flood Economic Readiness & & & $\begin{array}{l}1.763^{+} \\
(0.907)\end{array}$ & $\begin{array}{l}1.595^{+} \\
(0.935)\end{array}$ \\
\hline Trump Vote 2016 & & & & $\begin{array}{c}0.683 \\
(1.801)\end{array}$ \\
\hline Total Population (Log) & & & & $\begin{array}{c}0.247 \\
(0.163)\end{array}$ \\
\hline Median Income & & & & $\begin{array}{c}0.000 \\
(0.000)\end{array}$ \\
\hline Pct. Below 12th Grade Education & & & & $\begin{array}{l}-0.029 \\
(0.033)\end{array}$ \\
\hline Constant & $\begin{array}{c}81.414^{* * *} \\
(0.472)\end{array}$ & $\begin{array}{c}82.294^{* * *} \\
(0.947)\end{array}$ & $\begin{array}{c}79.257^{* * *} \\
(0.987)\end{array}$ & $\begin{array}{c}72.747^{* * *} \\
(3.036)\end{array}$ \\
\hline Observations & 218 & 158 & 158 & 158 \\
\hline$R^{2}$ & 0.016 & 0.045 & 0.209 & 0.281 \\
\hline
\end{tabular}

Standard errors in parentheses

${ }^{+} p<0.1,{ }^{*} p<0.05,{ }^{* *} p<0.01,{ }^{* * *} p<0.001$ 